\title{
Interaction of Herbal Compounds with Biological Targets: A Case Study with Berberine
}

\author{
Xiao-Wu Chen, ${ }^{1}$ Yuan Ming Di, ${ }^{2}$ Jian Zhang, ${ }^{3}$ Zhi-Wei Zhou, ${ }^{2}$ \\ Chun Guang $\mathrm{Li}^{2}{ }^{2}$ and Shu-Feng $\mathrm{Zhou}^{2,4}$ \\ ${ }^{1}$ Department of General Surgery, The First People's Hospital of Shunde, Southern Medical University, \\ Shunde, Guangdong 528300, China \\ ${ }^{2}$ School of Health Sciences and Health Innovations Research Institute, RMIT University, Bundoora, VIC 3083, Australia \\ ${ }^{3}$ Department of Surgery, The Third Hospital of Nanchang, Jiangxi, Nanchang 330009, China \\ ${ }^{4}$ Department of Pharmaceutical Science, College of Pharmacy, University of South Florida, 12901 Bruce B. Downs Boulevard, \\ MDC 30, Tampa, FL 33612, USA
}

Correspondence should be addressed to Shu-Feng Zhou, szhou@health.usf.edu

Received 7 June 2012; Accepted 8 July 2012

Academic Editors: H.-W. Chang, L.-Y. Chuang, and S. Yasmin

Copyright () 2012 Xiao-Wu Chen et al. This is an open access article distributed under the Creative Commons Attribution License, which permits unrestricted use, distribution, and reproduction in any medium, provided the original work is properly cited.

\begin{abstract}
Berberine is one of the main alkaloids found in the Chinese herb Huang lian (Rhizoma Coptidis), which has been reported to have multiple pharmacological activities. This study aimed to analyze the molecular targets of berberine based on literature data followed by a pathway analysis using the PANTHER program. PANTHER analysis of berberine targets showed that the most classes of molecular functions include receptor binding, kinase activity, protein binding, transcription activity, DNA binding, and kinase regulator activity. Based on the biological process classification of in vitro berberine targets, those targets related to signal transduction, intracellular signalling cascade, cell surface receptor-linked signal transduction, cell motion, cell cycle control, immunity system process, and protein metabolic process are most frequently involved. In addition, berberine was found to interact with a mixture of biological pathways, such as Alzheimer's disease-presenilin and -secretase pathways, angiogenesis, apoptosis signalling pathway, FAS signalling pathway, Hungtington disease, inflammation mediated by chemokine and cytokine signalling pathways, interleukin signalling pathway, and p53 pathways. We also explored the possible mechanism of action for the antidiabetic effect of berberine. Further studies are warranted to elucidate the mechanisms of action of berberine using systems biology approach.
\end{abstract}

\section{Introduction}

The majority of clinical drugs achieve their effect by binding to a cavity and regulating the cavity, of its protein targets [1]. In general, drugs act on four main types of regulatory proteins that mediate the actions of hormones, neurotransmitters, and autacoids. These four types of regulatory proteins are carriers, proteins, ion channels, and receptors [2]. Certain characteristics are expected for therapeutic targets [3]. A potential target needs only not to be druggable but also linked to disease, most preferably playing critical and inimitable roles in disease state. Binding sites are to have certain structural and physiochemical properties to accommodate high-affinity site-specific binding and subsequent regulation of protein activity by drugs. They are not significantly involved in other important biological processes to avoid potential side effects. Useful information about these targets may be investigated by analysing their sequence properties, protein families, structural folds, biochemical classes, similarity proteins, gene location in the human genome, and associated pathways [4]. This information can be potentially useful in derivation of rule and developing predictive tools in the search for druggable and potential targets [4].

The number of molecular targets acted on by current drug therapy is still in dispute. In 1996, Drews and Ryser identified a total of 483 drug targets addressed by drug therapy $[5,6]$. Approximately $45 \%$ are cell membrane receptors, $28 \%$ are enzymes, and the remaining classes comprise 
hormones $(11 \%)$, ion channels $(5 \%)$, nuclear receptors $(2 \%)$, and DNA $(2 \%)$. About $7 \%$ of the targets are not known biochemically. Later, Hopkins and Groom challenged this figure and suggested that "rule-of-five" compliant drugs acted primarily through only 120 underlying molecular targets $[3,7]$. However, the statistical analysis of disease genes and related proteins suggested that the total number of the estimated potential targets in the human genome ranges from 600 to 1,500 [3]. In the meantime, another report showed the estimated total number of distinct targets is in the range of 1,700-3,000 [8]. Chen et al. reported targets collected in the Therapeutic Target Database [9] is 997 distinct proteins, 1,494 distinct protein subtypes, and 41 nucleic acids, which are only targeted by at least one marketed drug and 1,267 research targets, which are only targeted by investigational agents that are not approved for clinical use at present [4]. Targets for neoplasm diseases, circulatory system diseases, infectious diseases, and nervous system and sense organs disorders constitute the largest number of targets [1]. An increase in target numbers is made possible by advances in genomics, proteomics, better molecular understanding of diseases, and increased effort in the exploration of new therapeutic targets as well as increased knowledge of unknown or unreported targets of previous existing drugs. An improvement in technology for target identification and validation also contributes greatly.

Chinese herbal medicine (CHM) has always been an integral part of traditional Chinese medicine (TCM), which has been practiced in the east for thousands of years. Chinese herbs are usually in the forms of dried whole plants or parts of the plants (roots, leaves, body, etc.); sometimes shells and even minerals are used. Chinese herbs are often used in a compound formula, consisting of several different herbs hosting different roles according to the principle of JunChen-Zuo-Shi described by the ancient Chinese. Each of Jun, Chen, Zuo, and Shi function together to harmonise the body, with Shi (courier) herbs are included in many formulae to ensure that all components in the prescription are well absorbed and to help to deliver or guide them to the target organs [10]. On some level, the guiding function of Shi herbs relates to modern drug delivery techniques, guiding the drug compound to target tissues. In the modern world, complementary medicine has gained vast popularity in the West. There has been increased use of herbal medicine to manage chronic diseases and promote wellbeing, in countries such as Australia, New Zealand, USA, and Europe [11]. Reports show that $18.9 \%$ of the American population used natural products in the precedent year [12]. This increase in popularity is closely related to its proven effectiveness in clinical practice over the past centuries. To date, more than 11,000 species of plants are used medicinally and about 300 are commonly used [13].

Despite its widespread use, CHM is associated with high levels of uncertainty. This is mainly due to lack of evidence, base of efficacy, targets, and safety data. During the process of therapeutic drug development, owing to the preselection of targets, researchers have a basic if not full understanding of which molecular structures the drug will react with or which biological pathway in the body it might alter. Knowledge on molecular interactions and modulations of the drug is anticipated and researched on. However, this is not the case for CHM. There is no preselection of molecular targets in the body but CHM has been used for thousands of years and is proven to be effective. The exact mechanism of the herbs actions is yet to be elucidated.

The proven clinical efficacy of some herbal medicines is considered to be due to the interaction of pharmacologically active components from the herbs with molecular targets in the body. Similar to synthetic drugs, active compounds of herbal medicine may bind to and undergo interactions with molecular structures or herbal targets to produce therapeutic or adverse effects. However, there is a lack of understanding of how CHMs exert their biological and clinical effects at a molecular level, which impedes development of CHMs and the incorporation of CHMs into mainstream medicine in the West.

Berberine (Figure 1, molecular formula $\mathrm{C}_{20} \mathrm{H}_{19} \mathrm{NO}_{5}$ and a molecular weight of 353.36) is an isoquinoline alkaloid found in many medicinal plants [14]. It is a major constituent of many medicinal plants of families Papaveraceae, Berberidaceae, Fumariaceae, Menispermaceae, Ranunculaceae, Rutaceae, and Annonaceae [15]. It is present in Hydrastis canadensis (goldenseal), Coptis chinensis (Coptis or goldenthread), Berberis aquifolium (Oregon grape), Berberis vulgaris (barberry), and Berberis aristata (tree turmeric). The berberine alkaloid can be found in the roots, rhizomes, and stem bark of the plants. Berberine is one of the main alkaloids found in the Chinese herb Huang Lian (Rhizoma coptidis) [16]. Huang Lian has traditionally been used to treat diarrhoea and diabetes. In China, berberine has been manufactured into the over-the-counter drug Huang Lian Su Pian, also known as Coptis Extract Tablets for the treatment of traveler's diarrhoea $[14,17]$. In recent years, there has been a growing interest in the pharmacological activities of berberine and many studies have been carried out to elucidate the mechanisms of action of berberine. This study aims to review molecular targets of berberine based on in vitro studies. Berberine has shown to have good hypoglycaemic effects, so we also reviewed the effects of berberine in animal and human studies, with a focus on diabetes mellitus.

\section{Methods}

2.1. Data Retrieval from the Literature. In vitro studies related to berberine and its targets were searched using Pubmed (from inception to April 2012). Search terms used were a combination of "berberine," "in vitro," "human cell," and "mechanism." Only studies using human cell lines were used to extract current berberine targets. Studies using animal cell lines or berberine derivatives or in a language other than English were excluded. Information extracted from these studies includes molecular targets of berberine (name and gene symbols), cell type, effects of berberine, and possible clinical applications.

2.2. PANTHER Analysis. Using the PANTHER Classification System, in vitro berberine targets were analysed using three 


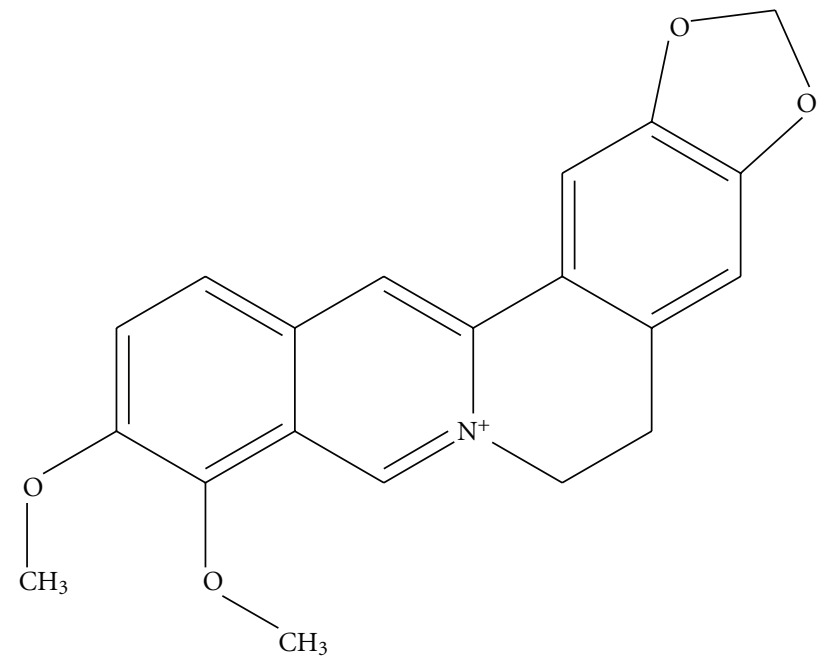

FIGURE 1: Chemical structure of berberine.

approaches: molecular function, biological process, and pathway involvement Table 2. PANTHER is a publicly available database that relates protein sequence evolution to evolution of protein functions and biological roles (http://www.pantherdb.org/).

\section{Results}

3.1. Targets of Berberine. A total of 90 berberine targets were identified in our literature search, as shown in Table 1.

Extensive research has been carried out to study the effects of berberine on cancer cells in vitro. This may be related to recent discovery of anti-cancer drugs with natural compound origin, for example, paclitaxel and topotecan.

Various human cancer cell lines were used to demonstrate the anti-cancer effects of berberine in vitro. These include cancer cell lines of the tongue, stomach, lung, colon, liver, breast, prostate, nasopharyngeal, neurones, epidermal, and blood [18-28]. Berberine has shown to induce cancer cell death via several mechanisms such as regulation of apoptosis proteins and cell cycle arrest.

Berberine treatment increased the expression of apoptotic cell death proteins, promotes cell cycle arrest, and induces cell death in human cancer cell lines. For instance, in human prostate epithelial cells (PWR-1E), berberineincreased expression of BCL2-associated X protein (Bax) was observed after berberine treatment, inducing cell death and demonstrating pro-apoptotic properties [29]. Similar effects of berberine were observed in prostate carcinoma cells (DU145, PC-3, and LNCaP) [21, 30]. Berberine also increased levels of Bax in promyelocytic leukemia cells [31], gastric carcinoma cells [24], and lung cancer cells [20].

Berberine can also promote cell death by the regulation of antiapoptotic proteins. Decreased expression of antiapoptotic Bcl-2 protein was observed in human oral squamous cell carcinoma after berberine treatment [23]. Studies done in other cancer cell lines such as lung cancer, gastric cancer, and prostate cancer also showed reduced levels of Bcl-2 after berberine treatment $[20,21,24,30]$. Cell cycle arrest at different phases has also been observed in human cancer cell lines after treatment with berberine. In giant cell carcinoma and prostate carcinoma cells, berberine also decreased $\mathrm{G}_{0} / \mathrm{G}_{1}$ phase-associated cyclins ( $\mathrm{D}_{1}, \mathrm{D}_{2}, \mathrm{E}, \mathrm{Cdk} 2$, Cdk4, and Cdk6), inducing $\mathrm{G}_{0} / \mathrm{G}_{1}$ arrest and suppressing cell proliferation [21, 25, 30, 32]. Further, in HepG2 cells, berberine acted on Bcell CLL/lymphoma 2 (BCL2), procaspase- 3 and -9 , and poly (ADP-ribose) polymerase (PARP), induced cell cycle arrest at $\mathrm{G}_{2} / \mathrm{M}$ phase and inhibited cell proliferation [22].

Further, berberine can promote cell death via the regulation of pro- and antiapoptotic proteins. In addition to this, berberine can also promote apoptosis via mitochondrial/caspase pathway. In cancer cell lines (tongue cancer, oral squamous cell carcinoma and prostate epithelial) [18, $23,29,33]$, activation of caspases-3 \& -9 promotes $G_{1}$ cell cycle arrest in different human cancer cell lines (lung, stomach, and prostate) $[20,21,24,30,33]$.

Berberine also showed anti-metastatic properties in several cancer cell lines, acting on $72 \mathrm{kDa}$ type IV collagenase (MMP2), Cdc42 effector protein 1 (CDC42EP1), and rasrelated $\mathrm{C} 3$ botulinum toxin substrate 1 (RAC1), transforming protein RhoA (RHOA) and urokinase-plasminogen activator A (PLAU) [34, 35]. Further, berberine showed antitopoisomerase I properties [36]; this observation can be useful as topoisomerase I is responsible for DNA replication and antitopoisomerase I compounds can be effective in cancer treatments.

In addition to its effects on cancer cells, berberine also acts on molecular targets related to insulin resistance. In freefatty-acid-induced insulin resistance muscle cells, berberine improves insulin resistance and improves glucose uptake by decreasing PPAR $\gamma$ and FAT/CD36 protein expression [37]. Another study reported increased insulin receptor (InsR) mRNA and protein expression increases insulin sensitivity in liver cells after berberine treatment [38]. In Caco- 2 cells, berberine inhibited alpha-glucosidase and disaccharidases activities, leading to reduced glucose levels [39]. In Hep $\mathrm{G}_{2}$ 


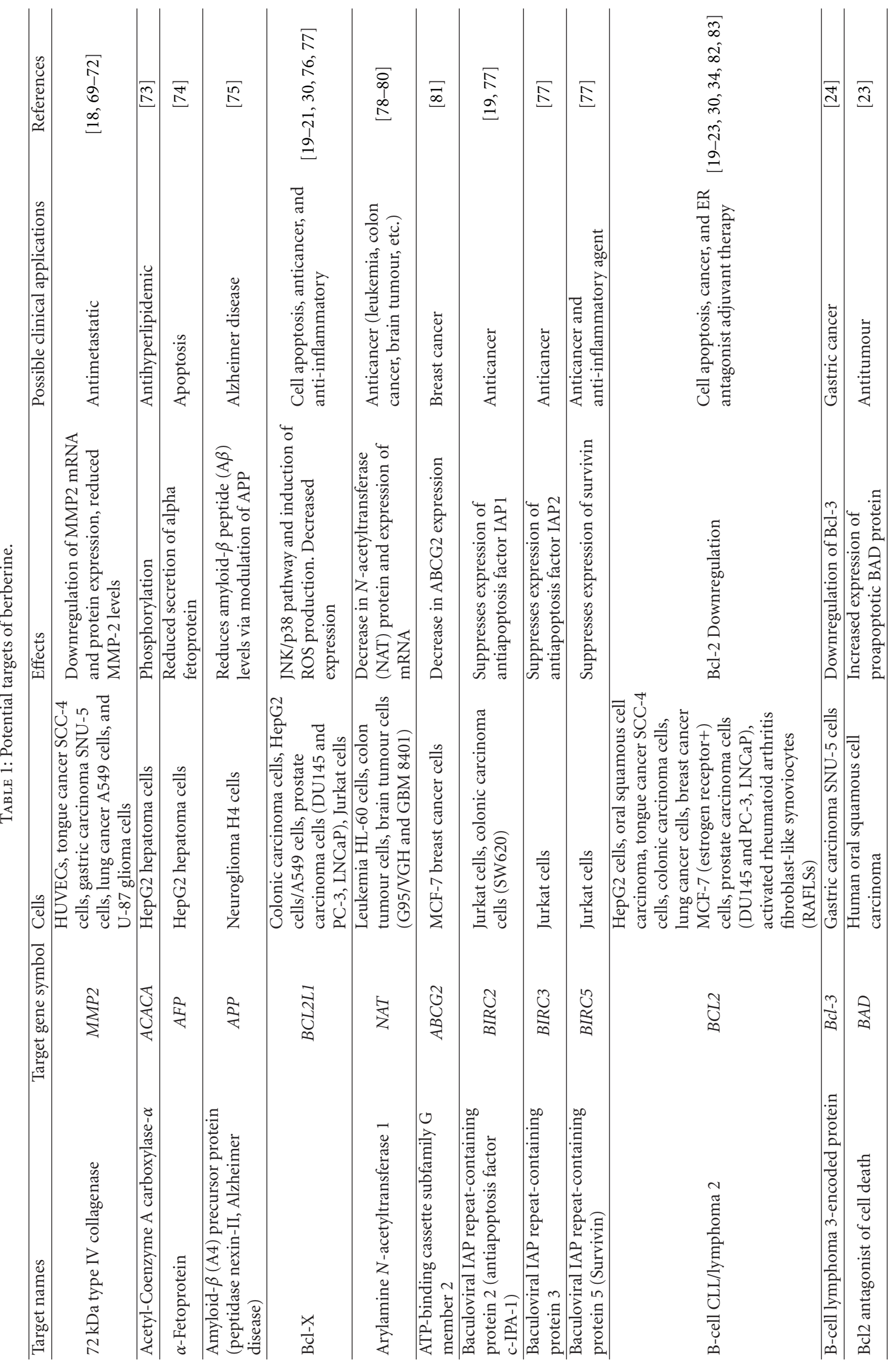




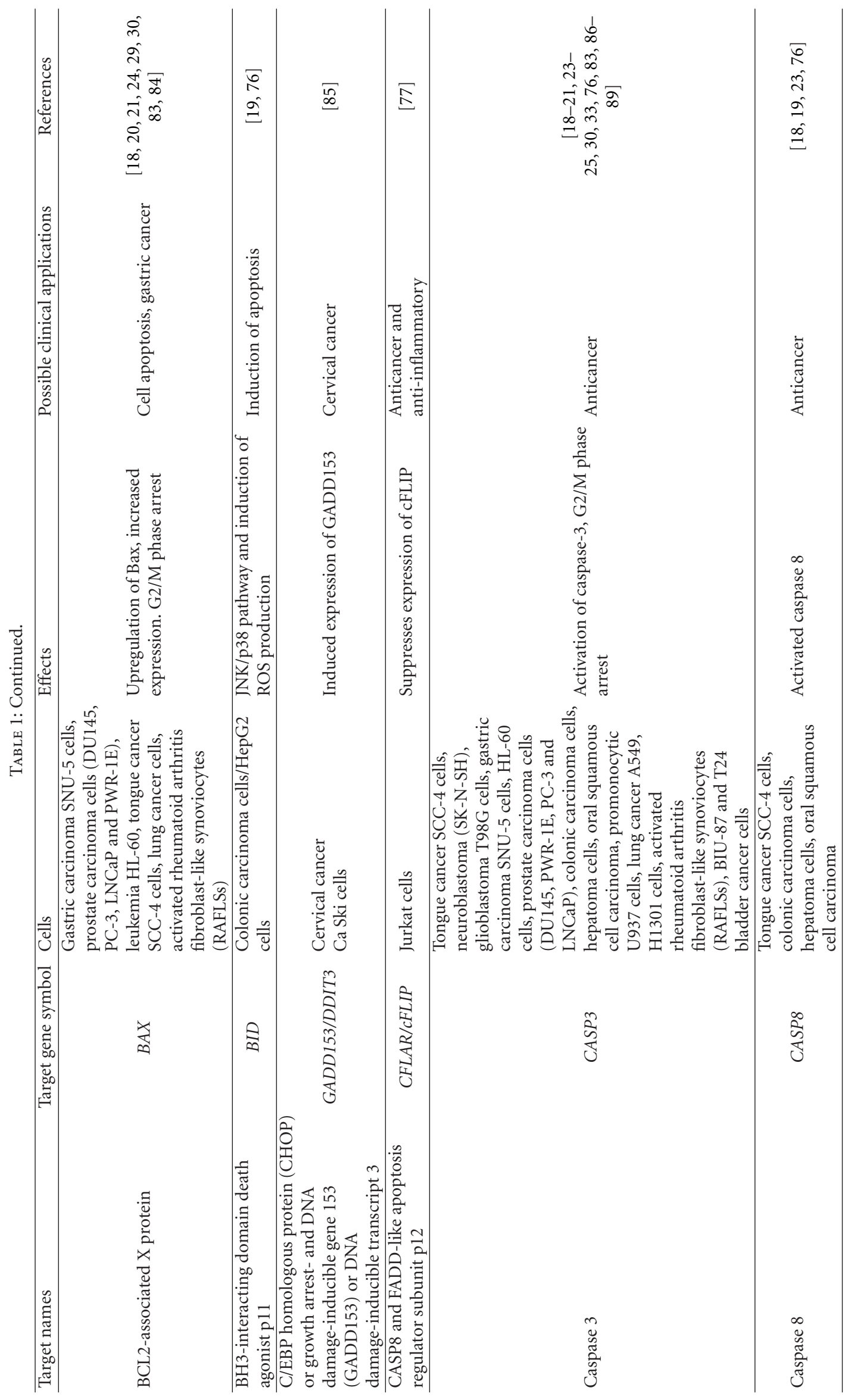




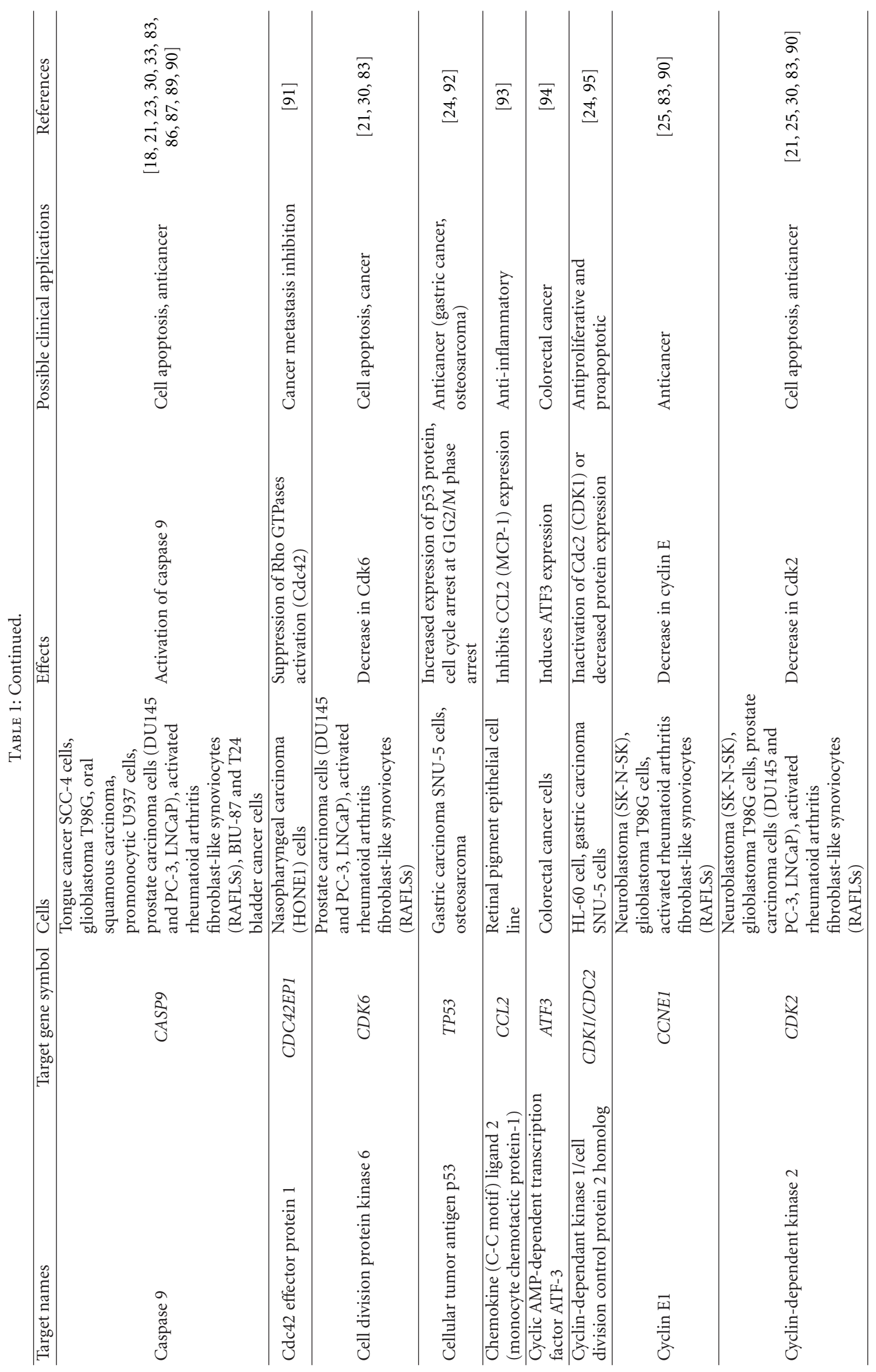




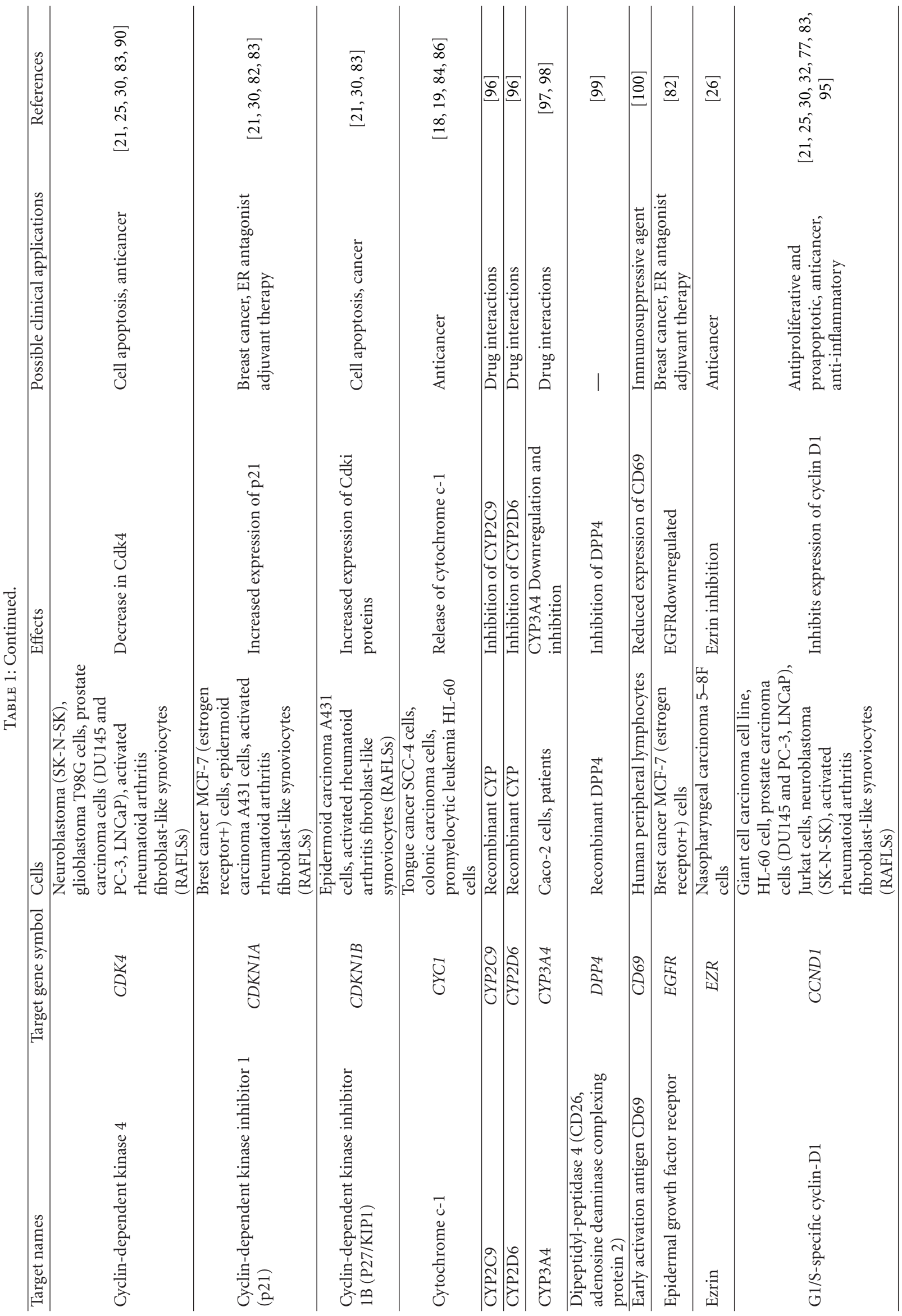




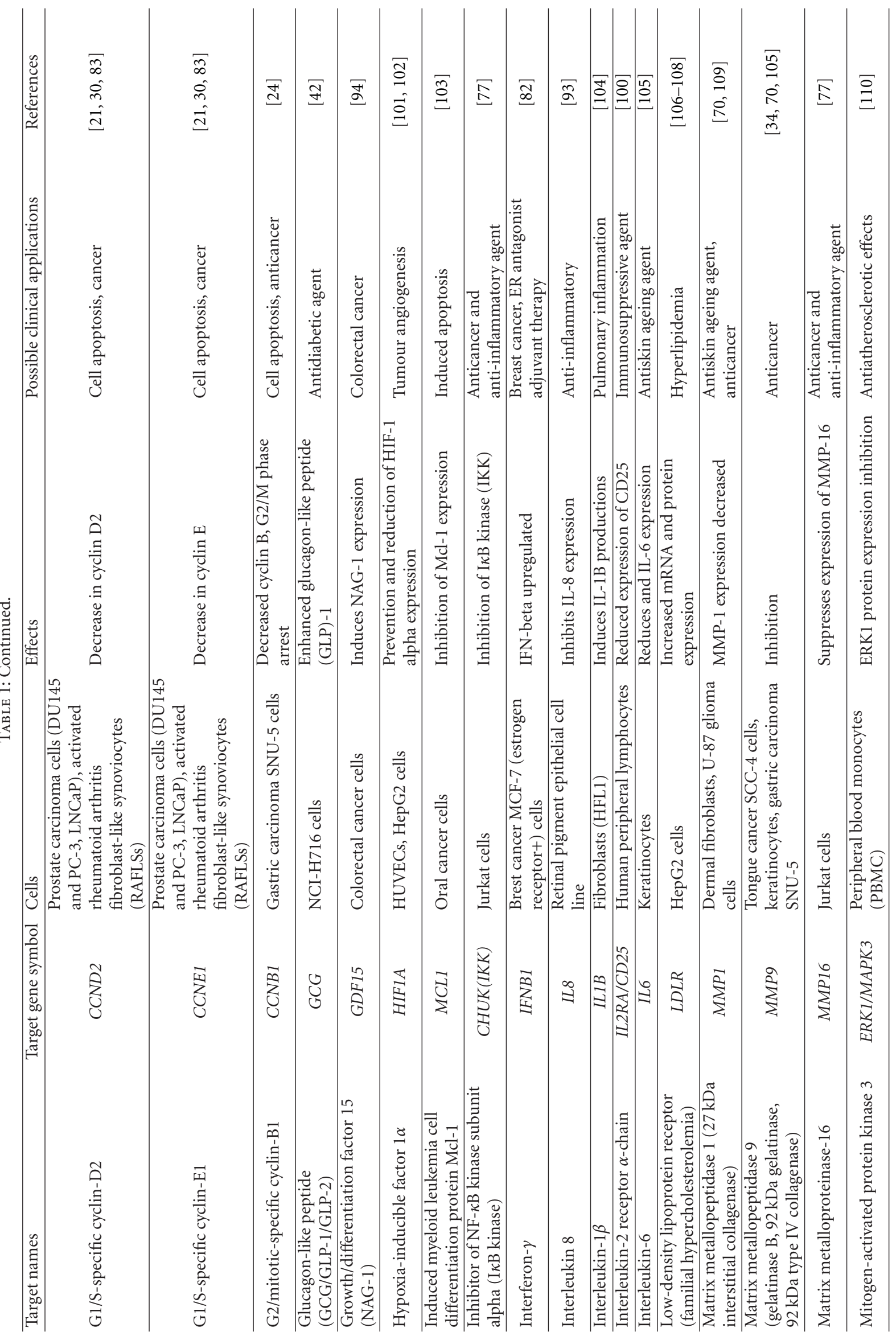




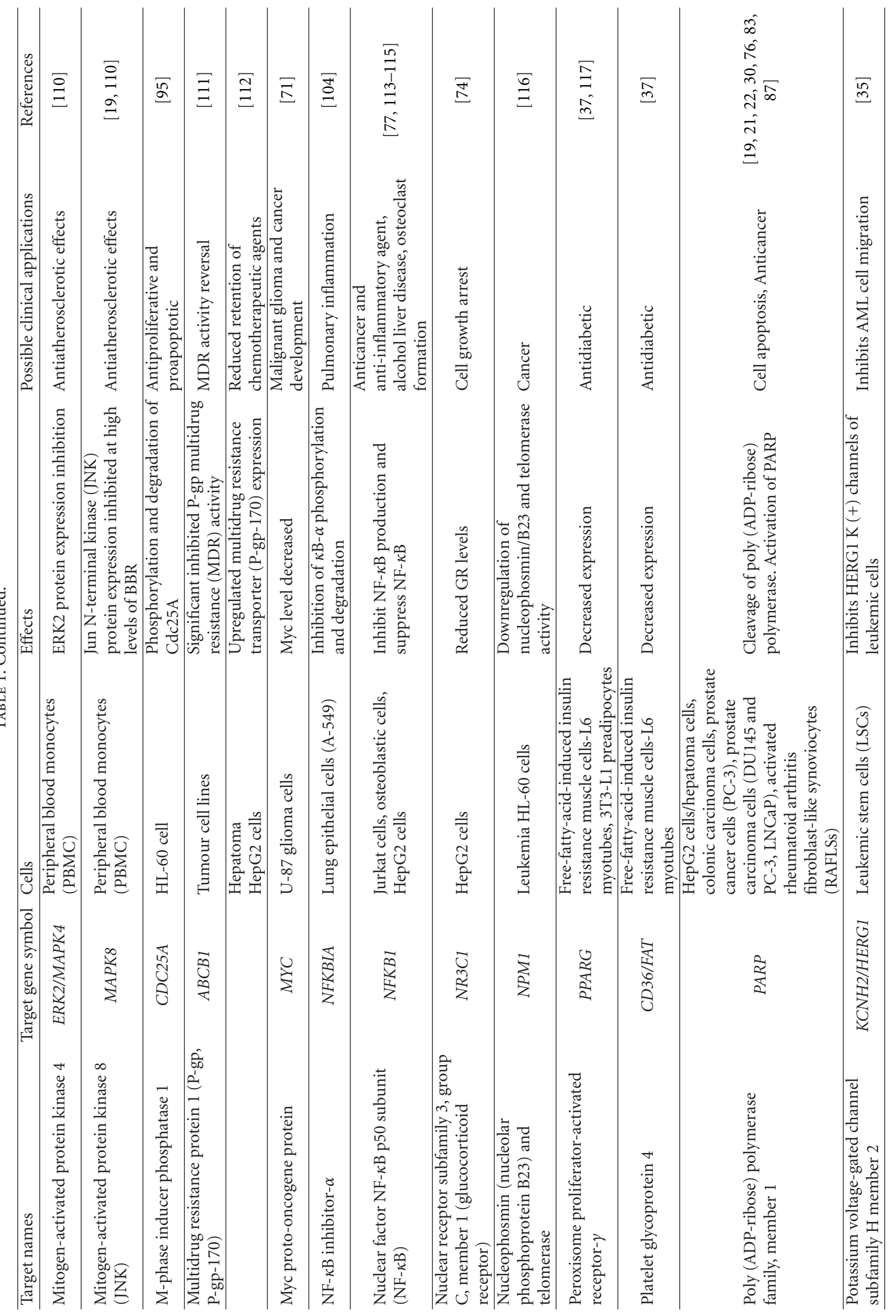




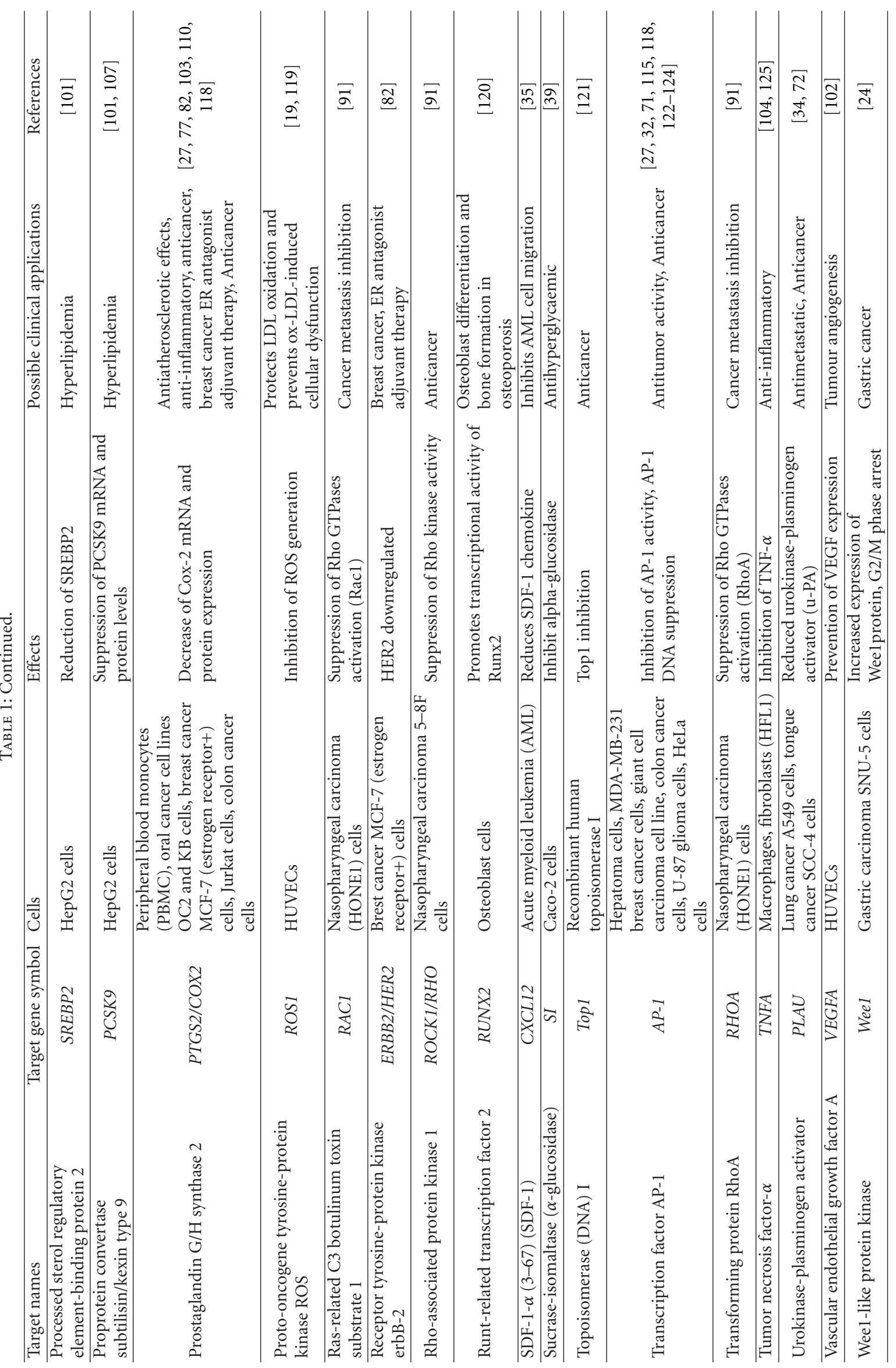




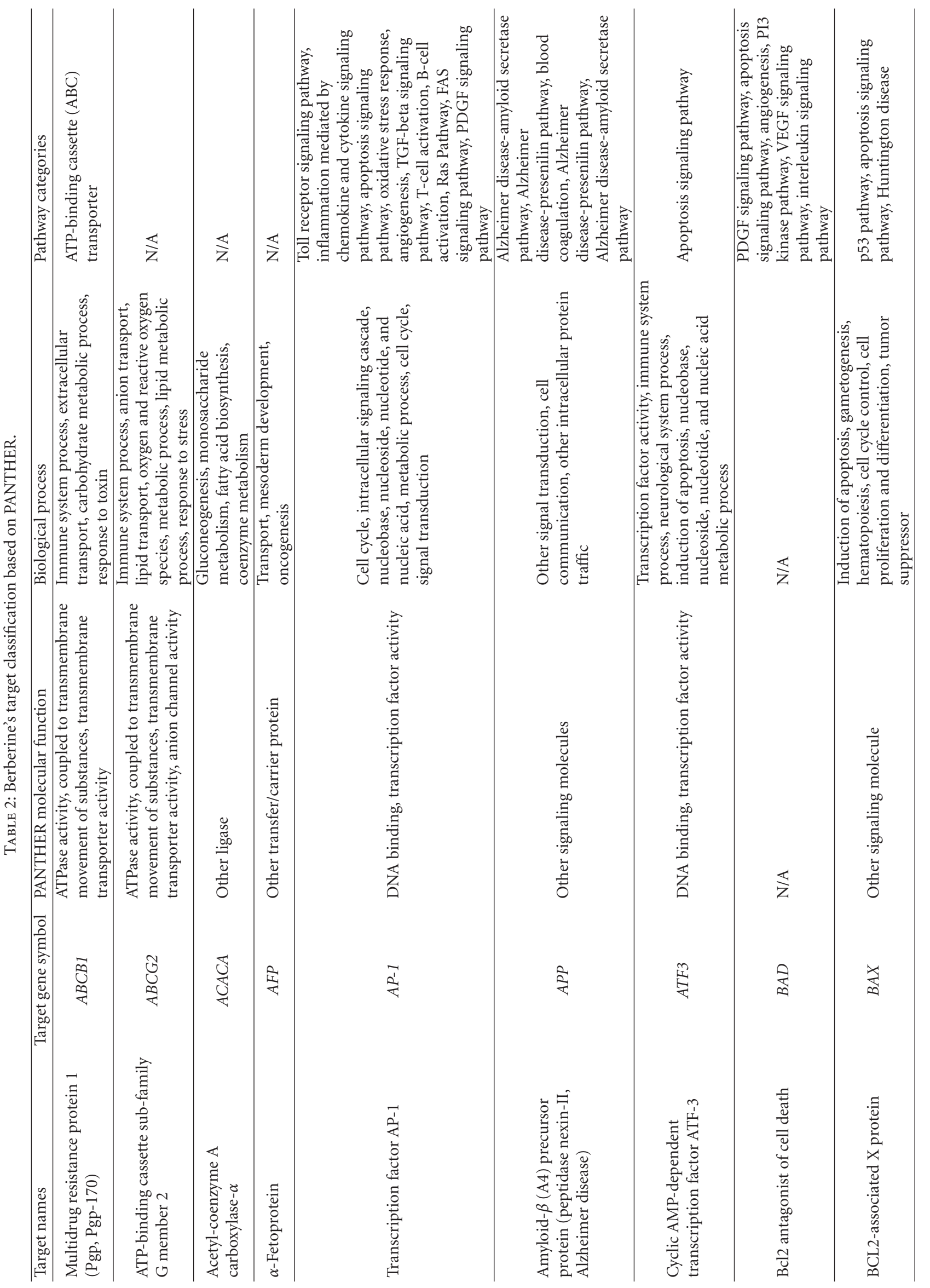




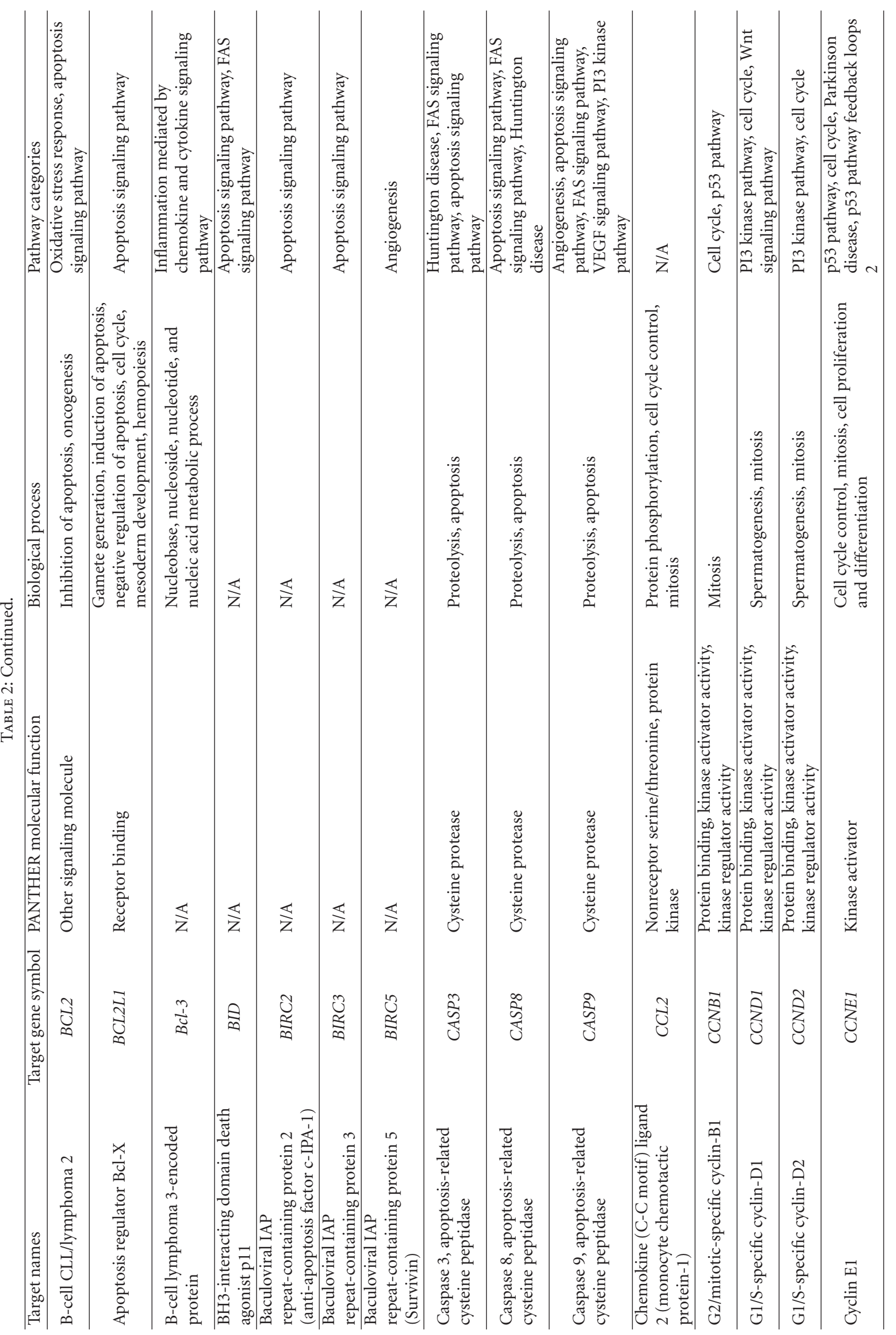




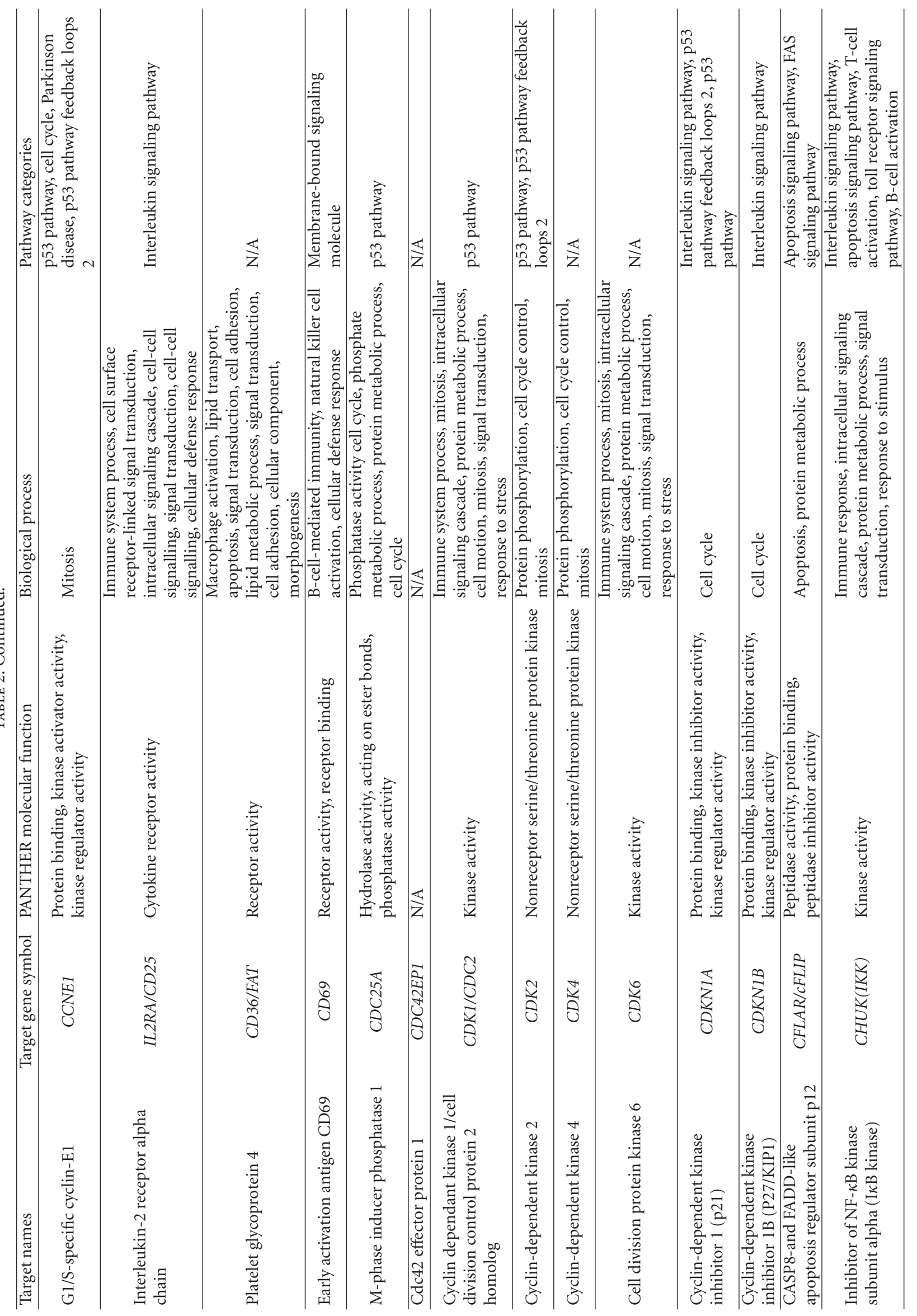




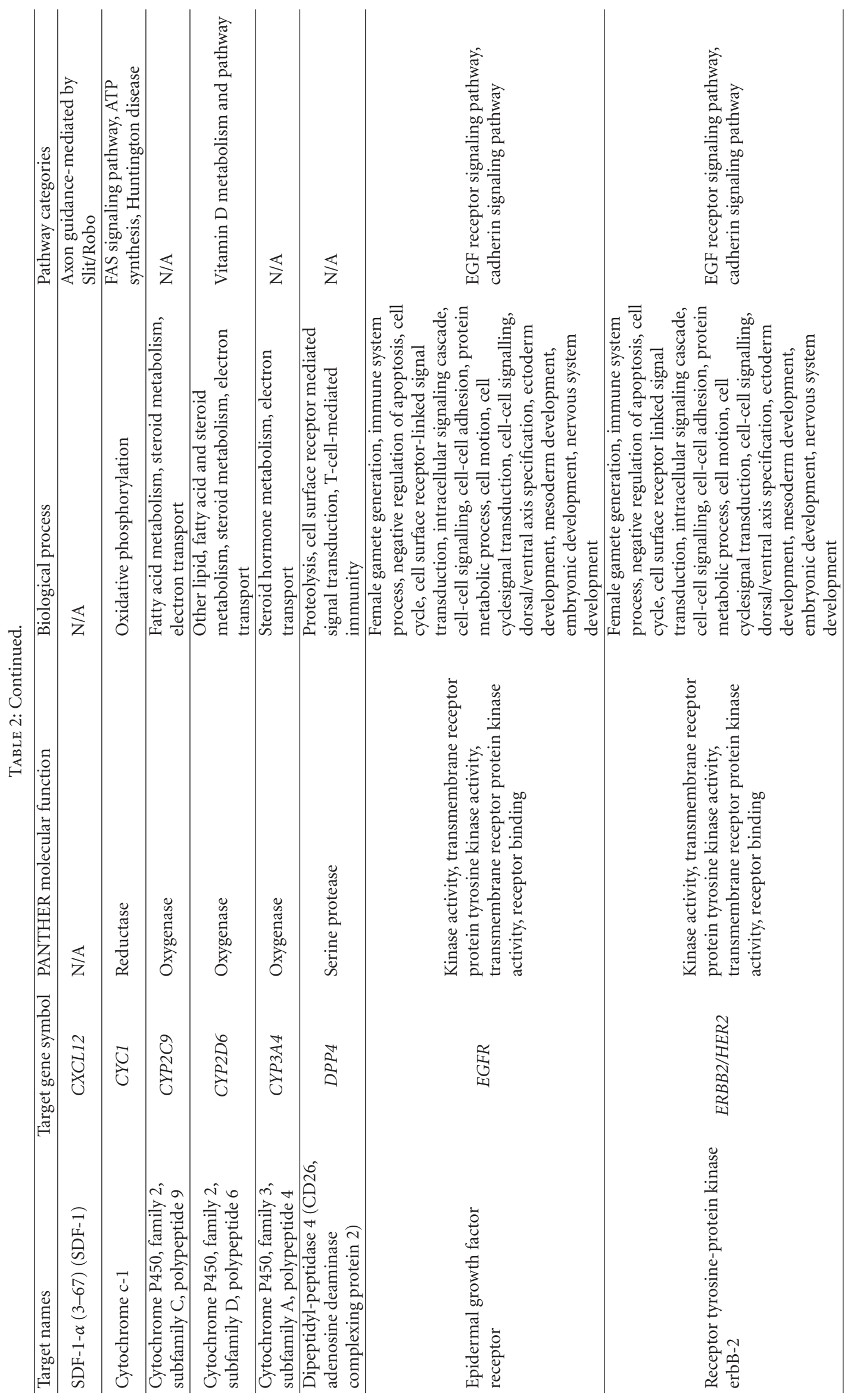




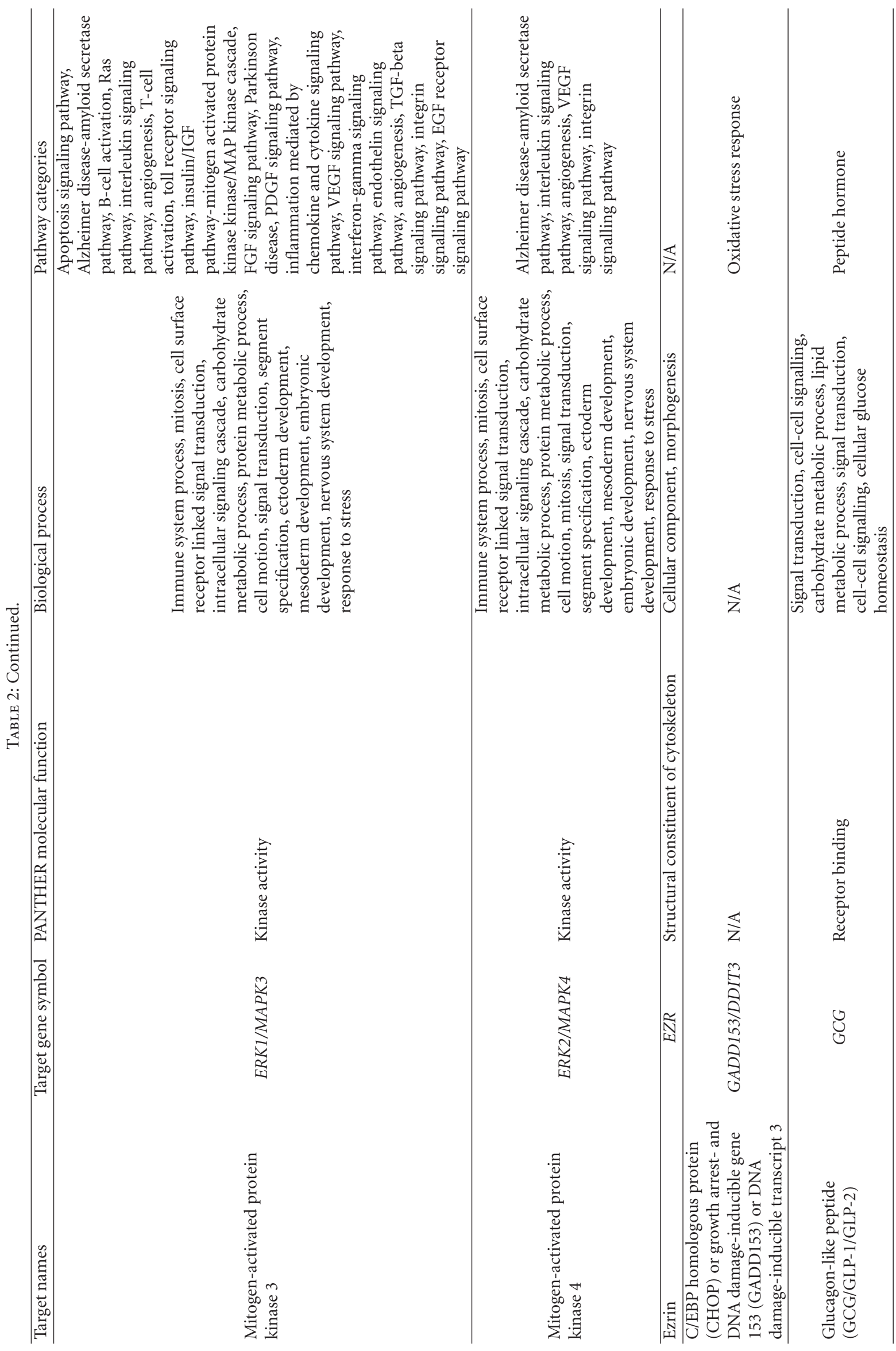




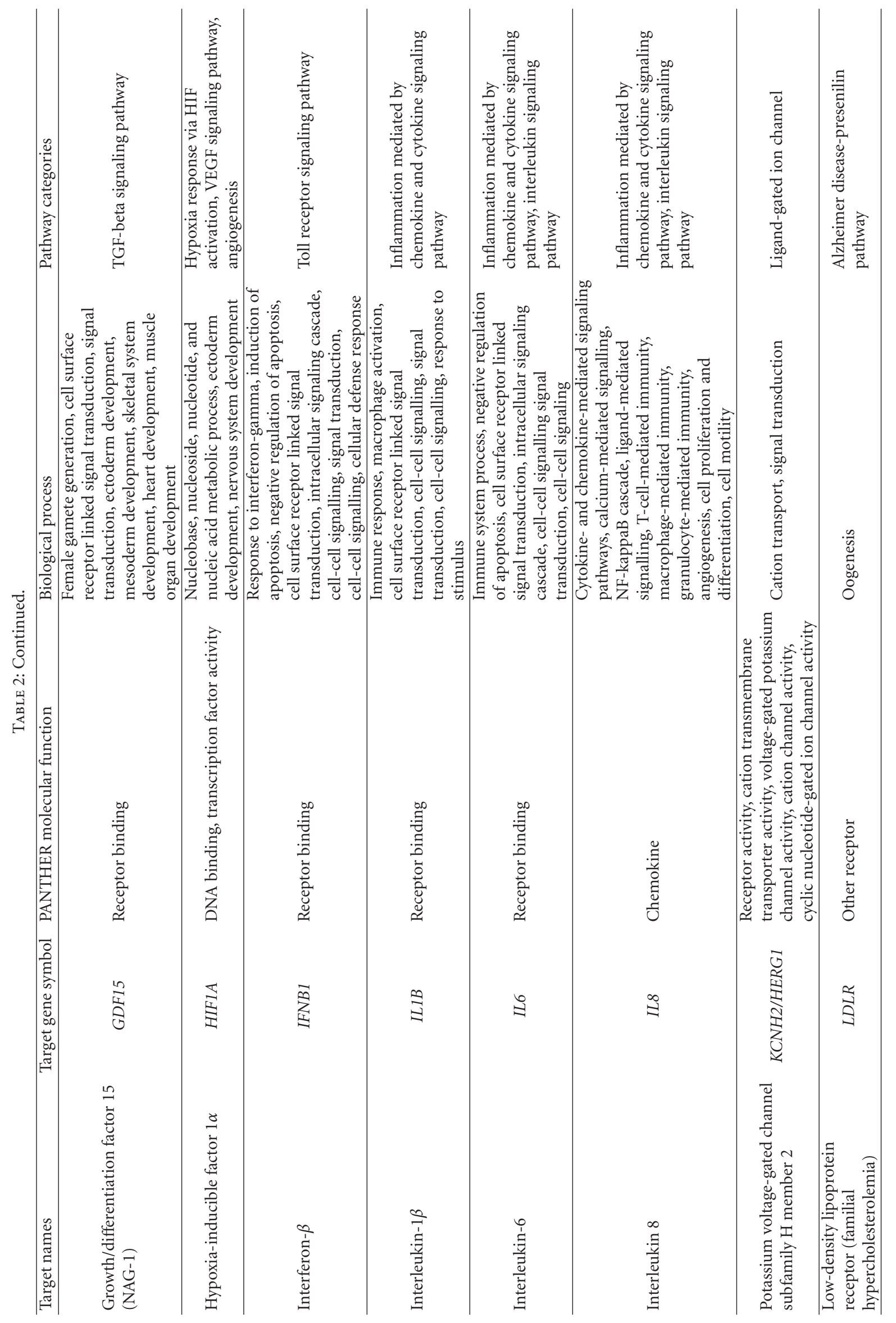




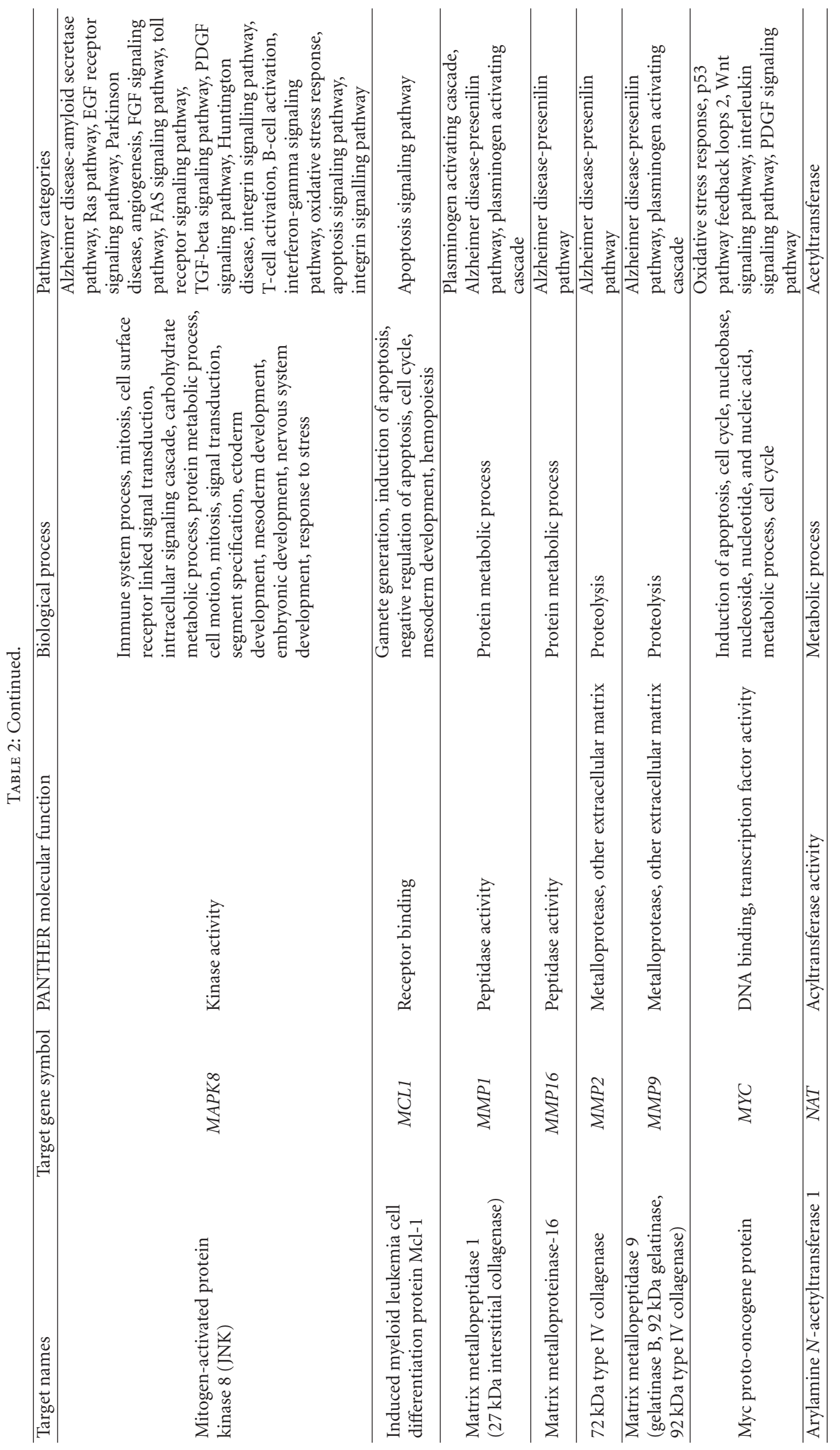




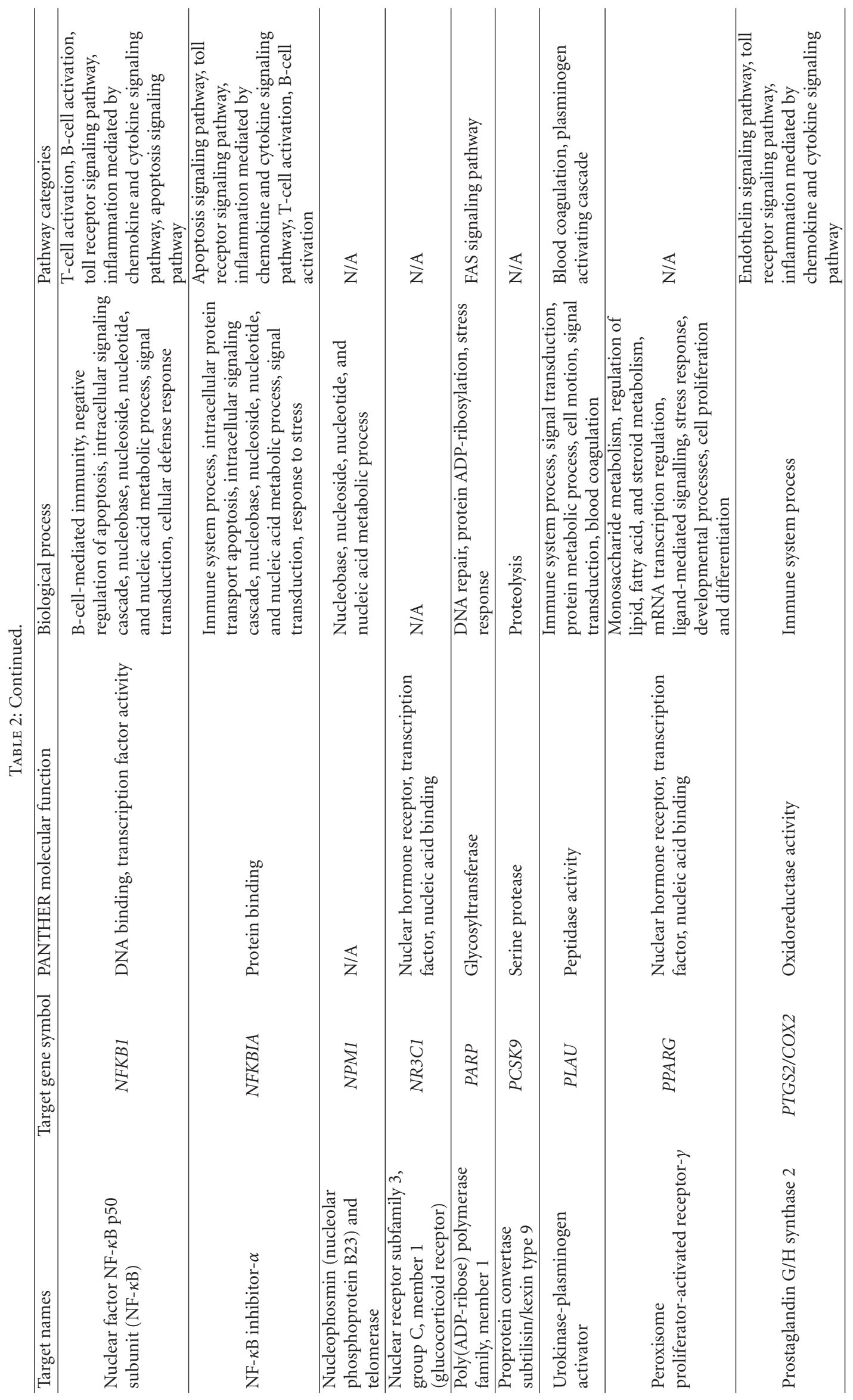




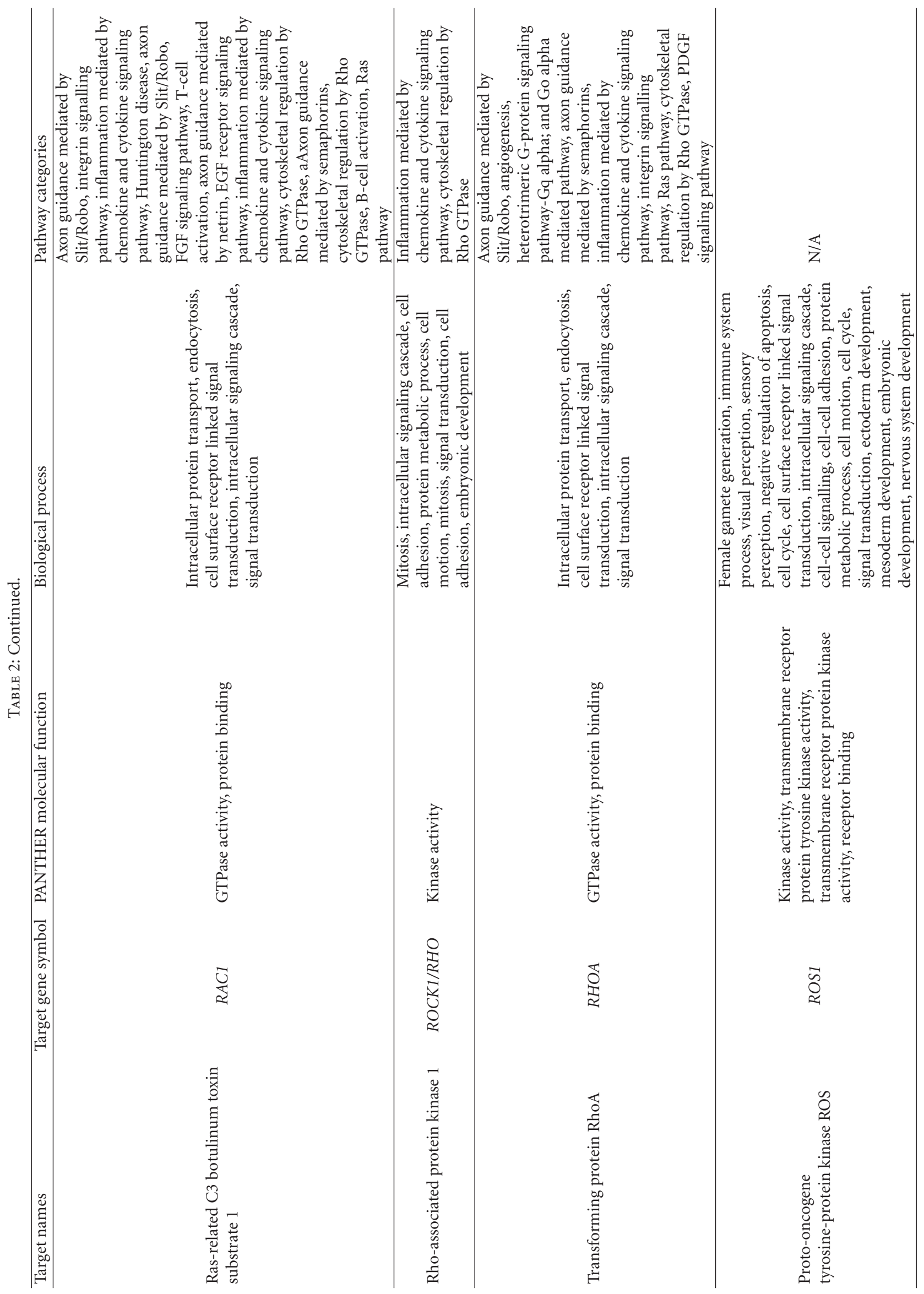




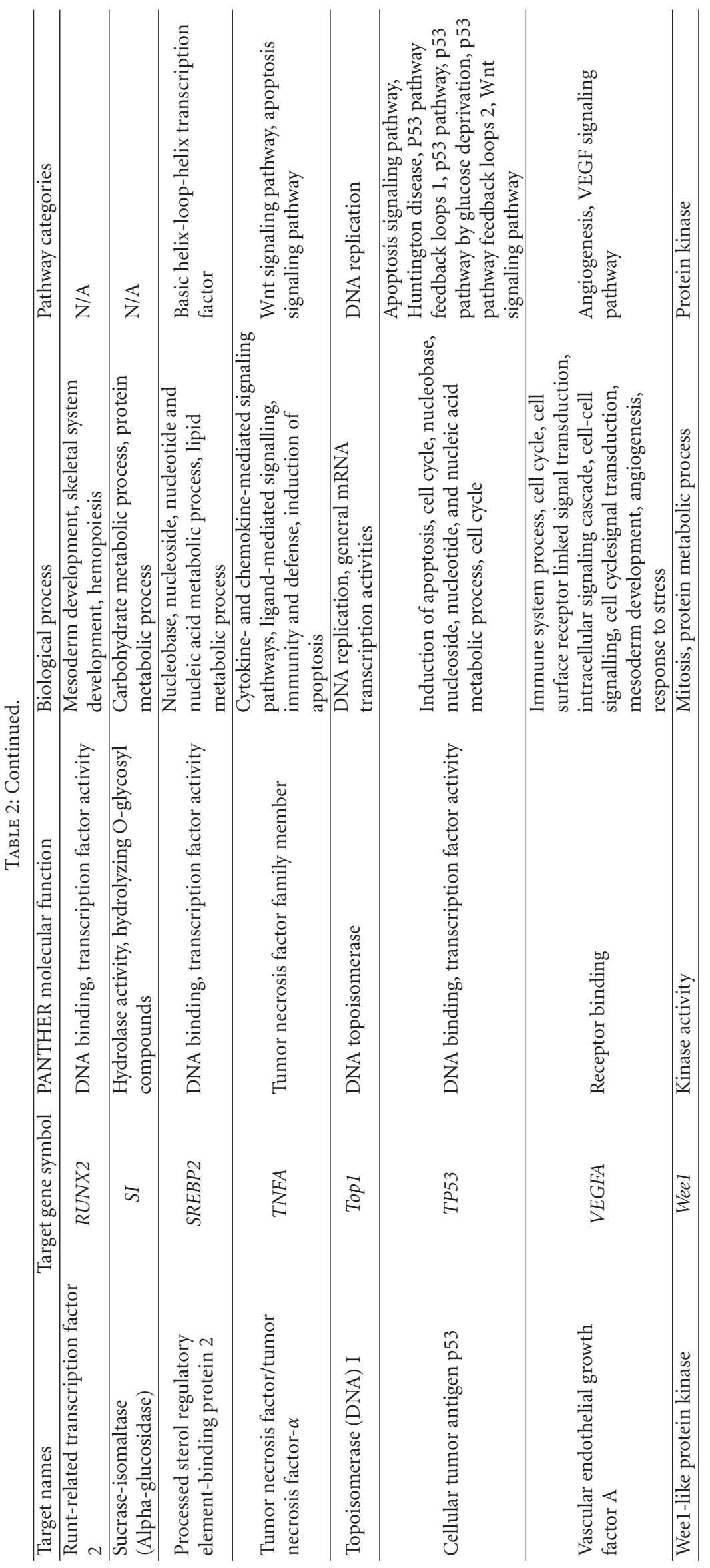


cells, berberine also improved insulin signal transduction through various mechanisms such as decreased phosphorylation of PERK and eLF2- $\alpha$, increased phosphorylation of IRS-1 tyrosine and AKT serine [40]. In intestinal NCI-H716 cells, berberine enhanced glucagon-like peptide 1 (GLP-1) release and promotes proglucagon mRNA expression [41]. These results demonstrate that berberine has great potential for insulin resistance treatment and should be explored further in animal and human studies.

3.2. PANTHER Analysis of Berberine Targets. Distribution of berberine therapeutic targets in vitro varied in each of these functional classifications. Tables 3, 4, and 5 show various distributions of the most frequent occurring berberine targets in vitro based on molecular functions, biological processes, and pathways, respectively.

As shown in Table 3, berberine acts on a diverse range of molecular targets in vitro. The most common classes of molecular functions include receptor binding, kinase activity, protein binding, transcription activity, DNA binding, and kinase regulator activity. Known berberine targets in vitro from the receptor binding class include epidermal growth factor receptor (EGFR), vascular endothelial growth factor A (VEGFA), interleukin-1 $\beta$ (IL1B) and interleukin-6 (IL6), growth/differentiation factor 15 (NAG-1), and glucagon-like peptide (GLP1).

Based on the biological process classification of in vitro berberine targets, those targets related to signal transduction, intracellular signalling cascade, cell surface receptor linked signal transduction, cell motion, cell cycle control, immunity system process, and protein metabolic process are most frequently involved (Table 4). In vitro berberine targets involved signal transduction include cyclin-dependant kinases (CDK1 and CDK6), inhibitor of nuclear factor kappa-B kinase subunit alpha (CHUK), epidermal growth factor receptor (EFGR), receptor tyrosine-protein kinase (ERBB2), glucagon-like peptide (GCG), growth/differentiation factor 15 (GDF15), interferon beta (IFNB1), interleukins (IL1B, IL2RA, and IL6), potassium voltage-gated channel subfamily $\mathrm{H}$ member 2 (KCNH1), mitogen-activated protein kinases (ERK1, ERK2, and MAPK8), nuclear factor-kappa-B p50 subunit (NFKB1), NF-kappa-B inhibitor alpha (NFKB1A), urokinase-plasminogen activator (PLAU), Ras-related C3 botulinum toxin substrate 1 (RAC1), Rho-associated protein kinase 4 (RHO), transforming protein RhoA (RHOA), proto-oncogene tyrosine-protein kinase ROS (ROS1), vascular endothelial growth factor A (VEGFA).

According to the PANTHER Classification System, in vitro berberine targets correlate with a mixture of biological pathways, such as Alzheimer disease-presenilin and secretase pathways, angiogenesis, apoptosis signalling pathway, FAS signalling pathway, Huntington disease, inflammation mediated by chemokine and cytokine signalling pathways, interleukin signalling pathway, and p53 pathways (Table 5 ).

The targets of berberine distributed across a large number of PANTHER classifications of molecular functions, biological processes, and pathways. This can be an advantage in terms of drug discovery using berberine. Seen that berberine targets are involved in a wide range of molecular
TABLE 3: Distribution of berberine's targets in vitro according to molecular functions.

\begin{tabular}{|c|c|}
\hline PANTHER molecular function & $\begin{array}{l}\text { Number } \\
\text { of targets }\end{array}$ \\
\hline Acyltransferase activity & 1 \\
\hline Anion channel activity & 1 \\
\hline $\begin{array}{l}\text { ATPase activity, coupled to transmembrane movement } \\
\text { of substances }\end{array}$ & 2 \\
\hline Cation channel activity & 1 \\
\hline Cation transmembrane transporter activity & 1 \\
\hline Chemokine & 1 \\
\hline Cyclic nucleotide-gated ion channel activity & 1 \\
\hline Cysteine protease & 3 \\
\hline Cytokine receptor activity & 1 \\
\hline DNA binding & 9 \\
\hline DNA topoisomerase & 1 \\
\hline Glycosyltransferase & 1 \\
\hline GTPase activity & 2 \\
\hline Hydrolase activity, acting on ester bonds & 1 \\
\hline Hydrolase activity, hydrolyzing O-glycosyl compounds & 1 \\
\hline Kinase activator & 1 \\
\hline Kinase activator activity & 4 \\
\hline Kinase activity & 11 \\
\hline Kinase inhibitor activity & 2 \\
\hline Kinase regulator activity & 6 \\
\hline Metalloprotease & 2 \\
\hline Not classified & 10 \\
\hline Non-receptor serine/threonine protein kinase & 3 \\
\hline Nuclear hormone receptor & 2 \\
\hline Nucleic acid binding & 2 \\
\hline Other extracellular matrix & 2 \\
\hline Other ligase & 1 \\
\hline Other receptor & 1 \\
\hline Other signaling molecule & 3 \\
\hline Other transfer/carrier protein & 1 \\
\hline Oxidoreductase activity & 1 \\
\hline Oxygenase & 3 \\
\hline Peptidase activity & 4 \\
\hline Peptidase inhibitor activity & 1 \\
\hline Phosphatase activity & 1 \\
\hline Protein binding & 10 \\
\hline Receptor activity & 3 \\
\hline Receptor binding & 12 \\
\hline Reductase & 1 \\
\hline Serine protease & 2 \\
\hline Structural constituent of cytoskeleton & 1 \\
\hline Transmembrane transporter activity & 2 \\
\hline Transcription factor & 2 \\
\hline Transcription factor activity & 9 \\
\hline Transmembrane receptor protein kinase activity & 3 \\
\hline $\begin{array}{l}\text { Transmembrane receptor protein tyrosine kinase } \\
\text { activity }\end{array}$ & 3 \\
\hline Tumor necrosis factor family member & 1 \\
\hline Voltage-gated potassium channel activity & 1 \\
\hline
\end{tabular}

activities, in turn, can alter many pathological states of the body. Thus, berberine can be explored for the treatment 
Table 4: Distribution of berberine's targets in vitro according to biological functions.

\begin{tabular}{|c|c|}
\hline PANTHER biological functions & $\begin{array}{l}\text { Number } \\
\text { of targets }\end{array}$ \\
\hline Angiogenesis & 2 \\
\hline Anion transport & 1 \\
\hline Apoptosis & 6 \\
\hline B-cell-mediated immunity & 2 \\
\hline Blood coagulation & 1 \\
\hline Calcium-mediated signaling & 1 \\
\hline Carbohydrate metabolic process & 7 \\
\hline Cation transport & 1 \\
\hline Cell adhesion & 3 \\
\hline Cell communication & 1 \\
\hline Cell cycle & 11 \\
\hline Cell cycle control & 5 \\
\hline Cell cycle intracellular signaling cascade & 1 \\
\hline Cell cycle signal transduction & 1 \\
\hline Cell motility & 1 \\
\hline Cell motion & 10 \\
\hline Cell proliferation and differentiation & 3 \\
\hline Cell proliferation and differentiation & 1 \\
\hline Cell surface receptor linked signal transduction & 14 \\
\hline Cell surface receptor-mediated signal transduction & 1 \\
\hline Cell-cell adhesion & 3 \\
\hline Cell-cell signaling & 9 \\
\hline Cellular component morphogenesis & 2 \\
\hline Cellular defense response & 4 \\
\hline Cellular glucose homeostasis & 1 \\
\hline Coenzyme metabolism & 1 \\
\hline Cytokine- and chemokine-mediated signaling pathways & 2 \\
\hline Developmental processes & 1 \\
\hline DNA repair & 1 \\
\hline DNA replication & 2 \\
\hline Dorsal/ventral axis specification & 1 \\
\hline Ectoderm development & 1 \\
\hline Ectoderm development & 8 \\
\hline Electron transport & 3 \\
\hline Embryonic development & 7 \\
\hline Endocytosis & 2 \\
\hline Extracellular transport & 2 \\
\hline Fatty acid biosynthesis & 1 \\
\hline Fatty acid metabolism & 1 \\
\hline Female gamete generation & 4 \\
\hline Gamete generation & 2 \\
\hline Gametogenesis & 1 \\
\hline General mRNA transcription activities & 1 \\
\hline Gluconeogenesis & 1 \\
\hline Granulocyte-mediated immunity & 1 \\
\hline Heart development & 1 \\
\hline Hematopoiesis & 1 \\
\hline
\end{tabular}

Table 4: Continued.

\begin{tabular}{|c|c|}
\hline PANTHER biological functions & $\begin{array}{l}\text { Number } \\
\text { of targets }\end{array}$ \\
\hline Hemopoiesis & 3 \\
\hline Immune response & 2 \\
\hline Immune system process & 16 \\
\hline Immune system processMitosis & 1 \\
\hline Immunity and defense & 1 \\
\hline Induction of apoptosis & 9 \\
\hline Intracellular protein transport & 3 \\
\hline Intracellular signaling cascade & 18 \\
\hline Ligand-mediated signaling & 3 \\
\hline Lipid metabolic process & 4 \\
\hline Lipid transport & 2 \\
\hline Macrophage activation & 2 \\
\hline Macrophage-mediated immunity & 1 \\
\hline Mesoderm development & 12 \\
\hline Metabolic process & 1 \\
\hline Mitosis & 4 \\
\hline Monosaccharide metabolism & 2 \\
\hline mRNA transcription regulation & 1 \\
\hline Muscle organ development & 1 \\
\hline Not classified & 9 \\
\hline Natural killer cell activation & 1 \\
\hline Negative regulation of apoptosis & 8 \\
\hline Nervous system development & 7 \\
\hline Neurological system process & 1 \\
\hline $\mathrm{NF}-\kappa \mathrm{B}$ cascade & 1 \\
\hline $\begin{array}{l}\text { Nucleobase, nucleoside, nucleotide, and nucleic acid } \\
\text { metabolic process }\end{array}$ & 10 \\
\hline Oncogenesis & 3 \\
\hline Other intracellular protein traffic & 1 \\
\hline Other lipid, fatty acid and steroid metabolism & 1 \\
\hline Other signal transduction & 1 \\
\hline Oxidative phosphorylation & 1 \\
\hline Oxygen and reactive oxygen species metabolic process & 1 \\
\hline Phosphatase activity cell cycle & 1 \\
\hline Phosphate metabolic process & 1 \\
\hline Protein ADP-ribosylation & 1 \\
\hline Protein metabolic process & 17 \\
\hline Protein phosphorylation & 3 \\
\hline Proteolysis & 7 \\
\hline Regulation of lipid, fatty acid and steroid metabolism & 1 \\
\hline Response to interferon- $\gamma$ & 1 \\
\hline Response to stimulus & 2 \\
\hline Response to stress & 8 \\
\hline Response to toxin & 2 \\
\hline Segment specification & 3 \\
\hline Sensory perception & 1 \\
\hline Signal transduction & 25 \\
\hline
\end{tabular}


TABle 4: Continued.

\begin{tabular}{lc}
\hline PANTHER biological functions & $\begin{array}{c}\text { Number } \\
\text { of targets }\end{array}$ \\
\hline Skeletal system development & 2 \\
Spermatogenesis & 2 \\
Steroid hormone metabolism & 1 \\
Steroid metabolism & 2 \\
Stress response & 2 \\
T-cell-mediated immunity & 2 \\
Transcription factor activity immune system process & 1 \\
Transport & 1 \\
Tumor suppressor & 1 \\
Visual perception & 1 \\
\hline
\end{tabular}

of different diseases. On the other hand, the nature of multitargeting of berberine lacks in target specificity which can become difficult for drug design. Further, because berberine can have interactions with so many molecular structures and involve in different pathways, much attention must be paid to avoid interactions with other therapeutic drugs.

3.3. Data from In Vivo Studies with a Focus on Diabetes Mellitus. In China, Huang Lian (Rhizoma coptidis) has been used to treat diabetes for more than 1,400 years [16]. Berberine is one of the main active alkaloids present in Rhizoma Coptidis and has shown to have good hypoglycaemic effects in vitro $[37-39,42]$. Further, the chemical structure of berberine is different from the commonly used other hypoglycaemic agents such as sulphonylureas, biguanides, thiazolidinediones, or acarbose [14]. Thus, it is meaningful to investigate the efficacy and safety of berberine treatments for diabetes mellitus to confirm the possibility of berberine serving as a new class of antidiabetic medications. Extensive research has been done to investigate the hypoglycaemic effects of berberine in animal models. This section will highlight the effects of berberine in diabetic animal studies, focusing on different mechanisms of actions of berberine.

Hyperglycemia is a hallmark metabolic abnormality associated with metabolic diseases such as type 2 diabetes. Berberine has shown to significantly decrease fasting blood glucose levels in diabetic rats (diet or drug induced), this has been observed in a number of studies [43-46]. Berberine can reduce fasting blood glucose level via different mechanisms. For example, Liu et al. [43] reported that berberine reduced fasting blood glucose (FBG) levels by inhibiting intestinal disaccharidases in a concentration-dependent manner. Xia et al. [46] reported berberine reduced fasting glucose level via the inhibition of gluconeogenesis, via decreased PEPCK and G6Pase genes in the liver, reduced hepatic steatosis, and inhibition of FAS expression.

Current diabetes therapies do not address the key driver of this condition, $\beta$-cell dysfunction $[47,48]$, and do not alter the progressive nature of insulin secretory deficit [49]. Berberine increased pancreatic $\beta$-cell numbers and $\beta$-cell mass in streptozotocin-induced diabetic rats $[41,50]$. It also reversed pathological changes of pancreatic $\beta$-cells in diabetic rats induced by streptozotocin and diet [51]. Further,
TABLE 5: Distribution of berberine's targets in vitro according to pathway categories.

\begin{tabular}{|c|c|}
\hline PANTHER pathway categories & $\begin{array}{l}\text { Number } \\
\text { of targets }\end{array}$ \\
\hline Acetyltransferase & 1 \\
\hline Alzheimer disease-amyloid secretase pathway & 11 \\
\hline Alzheimer disease-presenilin pathway & 14 \\
\hline Angiogenesis & 11 \\
\hline Apoptosis signaling pathway & 21 \\
\hline ATP synthesis & 1 \\
\hline ATP-binding cassette $(\mathrm{ABC})$ transporter & 2 \\
\hline Axon guidance mediated by netrin & 1 \\
\hline Axon guidance mediated by semaphorins & 1 \\
\hline Axon guidance mediated by Slit/Robo & 4 \\
\hline B-cell activation & 7 \\
\hline Basic helix-loop-helix transcription factor & 1 \\
\hline Blood coagulation & 3 \\
\hline Cadherin signaling pathway & 2 \\
\hline Cell cycle & 4 \\
\hline Cytoskeletal regulation by Rho GTPase & 3 \\
\hline DNA replication & 2 \\
\hline EGF receptor signaling pathway & 4 \\
\hline Endothelin signaling pathway & 2 \\
\hline FAS signaling pathway & 13 \\
\hline FGF signaling pathway & 4 \\
\hline $\begin{array}{l}\text { Heterotrimeric G-protein signaling pathway-Gq } \\
\text { alpha- and Go alpha-mediated pathway }\end{array}$ & 1 \\
\hline Huntington disease & 9 \\
\hline Hypoxia response via HIF activation & 1 \\
\hline $\begin{array}{l}\text { Inflammation mediated by chemokine and cytokine } \\
\text { signaling pathways }\end{array}$ & 13 \\
\hline $\begin{array}{l}\text { Insulin/IGF pathway-mitogen activated protein kinase } \\
\text { kinase/MAP kinase cascade }\end{array}$ & 1 \\
\hline Integrin signalling pathway & 6 \\
\hline Interferon-gamma signaling pathway & 2 \\
\hline Interleukin signaling pathway & 10 \\
\hline Ligand-gated ion channel & 1 \\
\hline Membrane-bound signaling molecule & 1 \\
\hline Pathway unclassified & 19 \\
\hline Oxidative stress response & 5 \\
\hline p53 pathway & 12 \\
\hline p53 pathway by glucose deprivation & 1 \\
\hline p53 pathway feedback loops & 1 \\
\hline P53 pathway feedback loops 1 & 1 \\
\hline p53 pathway feedback loops 2 & 4 \\
\hline Parkinson disease & 3 \\
\hline PDGF signaling pathway & 6 \\
\hline Peptide hormone & 1 \\
\hline PI3 kinase pathway & 4 \\
\hline Plasminogen activating cascade & 8 \\
\hline
\end{tabular}


TABle 5: Continued.

\begin{tabular}{lc}
\hline PANTHER pathway categories & $\begin{array}{c}\text { Number } \\
\text { of targets }\end{array}$ \\
\hline Protein kinase & 1 \\
Ras Pathway & 5 \\
T-cell activation & 7 \\
TGF- $\beta$ signaling pathway & 4 \\
Toll receptor signaling pathway & 9 \\
VEGF signaling pathway & 7 \\
Vitamin D metabolism and pathway & 1 \\
Wnt signaling pathway & 4 \\
\hline
\end{tabular}

in berberine treated diabetic rats, the pancreatic and plasma insulin levels increased after glucose load, reducing blood glucose levels $[41,50]$. These observations are significant as berberine may be explored further as an additional therapy to existing antidiabetic drugs to effectively preserve $\beta$-cell functions, reverse $\beta$-cell damage, and promote insulin secretion in diabetes patients.

Further to $\beta$-cell dysfunction and insulin secretory deficit in diabetes, defects in insulin receptor (InsR) expression or function can cause insulin resistance and diabetes mellitus [52]. Thus, regulation of InsR expression may improve insulin resistance in diabetes mellitus. Berberine increases InsR mRNA and protein expression in human liver cells and in animal model in a dose- and time-dependent manner [38]. Berberine upregulates InsR and leads to enhanced insulin signalling pathway, confirming berberine as an insulin sensitiser.

Glucagon-like peptide 1 (GLP-1) is an intestinal peptide hormone released in response to food ingestion [53]. GLP1 enhances meal-related insulin secretion and promotes glucose tolerance. In streptozotocin-induced rats, berberine enhanced GLP-1 release and promotes proglucagon mRNA expression, increased beta cell mass and pancreas insulin levels after glucose load [41]. This observation was in line with the groups, previous experiments in vitro. Lu et al. [50] also reported that berberine increased proglucagon mRNA expression and plasma insulin levels in streptozotocininduced diabetic rats. The glucagon gene encodes GLP-1 and the increased expression of proglucagon mRNA assists in controlling the blood glucose homeostasis.

Berberine also reduced body weight and caused a significant improvement in glucose tolerance without altering food intake in $d b / d b$ mice [54]. Oral glucose tolerance improvement in diabetic rats after berberine treatment has also been observed in other studies $[55,56]$.

Long-term hyperglycaemia can lead to increased risk of cardiovascular complications. In hyperglycemia and hypercholesterolemia rats with injured cardiac functions, berberine $(15,30 \mathrm{mg} / \mathrm{kg} / \mathrm{day}$, i.g for 6 weeks $)$ increased cardiac output, left ventricular systolic pressure, and $+d p / d t_{\max }$ by 64 , 16 , and $79 \%$, but decreased left ventricular end diastolic pressure and $-d p / d t_{\max }$ by 121 and $61 \%$ in the rats receiving HSFD/streptozotocin, respectively, when compared with the untreated rats of hyperglycemia and hypercholesterolemia [57]. Berberine caused significant increase in cardiac fatty acid transport protein-1 (159\%), fatty acid transport proteins (56\%), fatty acid beta-oxidase $(52 \%)$, and glucose transporter-4. These results demonstrate the cardioprotective functions of berberine in hyperglycemia/hypercholesterolemia through alleviating cardiac lipid accumulation and promoting glucose transport 4 [57]. Another study also showed improved vasorelaxation in impaired aorta in diabetic rats after berberine treatment (100 mg/kg/day, 8 weeks) [45]. Thus, in addition to its hypoglycaemic effects, berberine can also be investigated for cardiomyopathy in diabetes.

Berberine also regulates lipid metabolism which is closely related to diabetes. In rats with induced diabetic hyperlipidemia, berberine $(75,150,300 \mathrm{mg} / \mathrm{kg} /$ day for 16 weeks) effectively reduced liver weight and liver/body weight ratio, levels of total cholesterol, triglycerides, and lowdensity lipoprotein-cholesterol [58]. In rats with a high fat diet, berberine significantly reduced body weight, alleviated liver steatosis, and improved insulin resistance [59]. This observation indicates that berberine can be an effective treatment for diabetes with obesity.

Clinically, preeminent factors for monitoring glycaemia and evaluating the risks of complications of diabetes include FBG, haemoglobin $\mathrm{A}_{1 \mathrm{c}}\left(\mathrm{HbA}_{1 \mathrm{c}}\right)$ [60]. Triglyceride synthesis is closely associated with glucose metabolism so serum triglyceride levels are determined. Clinical studies often measure $\mathrm{FBG}, \mathrm{HbA}_{1 \mathrm{c}}$, and triglyceride levels, along with other factors to study the hypoglycaemic effects of berberine. The efficacies of berberine in type 2 diabetes patients have been reported. Through literature search, key clinical studies on berberine effects on type 2 diabetes patients are summarised.

Zhang et al. [61] conducted a randomized, double-blind, placebo-controlled multicenter trial $(n=116)$. The authors found that when berberine ( $1.0 \mathrm{~g}$ daily) was administered for 3 months in type 2 diabetes patients with dyslipidemia, the fasting and postload plasma glucose levels decreased from $7.0 \pm 0.8$ to $5.6 \pm 0.9$ and from $12.0 \pm 2.7$ to $8.9 \pm$ $2.8 \mathrm{mM} / \mathrm{L}, \mathrm{HbA}_{1 \mathrm{c}}$ from $7.5 \pm 1.0 \%$ to $6.6 \pm 0.7 \%$. Further, in the treatment group, triglyceride levels were reduced from $2.51 \pm 2.04$ to $1.61 \pm 1.0 \mathrm{mM} / \mathrm{L}$, total cholesterol from $5.31 \pm 0.98$ to $4.35 \pm 0.96 \mathrm{mM} / \mathrm{L}$, and LDL-cholesterol from $3.23 \pm 0.81$ to $2.55 \pm 0.77 \mathrm{mM} / \mathrm{L}$. Results from the treatment group was significant compared to the control group. In the treatment group, patient's body weight was also significantly reduced. Mild-to-moderate constipation was reported in 5 patients from the treatment group and 1 patient from the control group; however, this finding was not statistically significant. No other adverse events were reported. At 3 months, berberine was found to be effective in lowering blood glucose, lipids, body weight, and blood pressure with a good safety profile.

Yin et al. reported a 3-month study comparing berberine to antidiabetic drug metformin $(0.5 \mathrm{~g}$ t.i.d) [14]. In this study, berberine exhibited identical effect as metformin in the regulation of glucose metabolism, significant decreases in $\mathrm{HbA}_{1 \mathrm{c}}$ (by $2 \%, P<0.01$ ), FBG (by $3.8 \mathrm{mmol} / \mathrm{L} ; P<0.01$ ), and postprandial blood glucose (PBG) (by $8.8 \mathrm{mmol} / \mathrm{L}$; $P<0.01)$. Further, the regulation of lipid metabolism was 
better in the berberine group than the metformin group. Triglycerides and total cholesterol levels were significantly lower than in the metformin group $(P<0.05)$. At the same time, the same group of researchers used berberine as a combination therapy to evaluate its additive or synergistic effects on the commonly used hypoglycemic agents, such as sulphonylureas, biguanides, thiazolidinediones, and acarbose. Patients were given $500 \mathrm{mg}$ berberine three times daily for 3 months in addition to their previous treatment. At week 5 , berberine significantly $(P<0.01)$ reduced $\mathrm{HbA}_{1 \mathrm{c}}$ (from $8.1 \%$ to $7.3 \%$ ), FBG, PBG, and fasting insulin levels. Blood lipids including triglyceride, total cholesterol, and LDL-C decreased significantly lowered compared to baseline. In both studies, incidences of gastrointestinal adverse events were observed, including diarrhea, constipation, flatulence, and abdominal pain. Interestingly, patients did not suffer from severe gastrointestinal adverse events when berberine was used alone and in combination therapy; adverse effects disappeared after berberine dosage was reduced. No pronounced elevation in liver enzymes or creatinine was observed, suggesting that berberine did not cause damage to the liver or kidneys.

Another clinical study [62] randomly divided 97 type 2 diabetes mellitus patients into berberine treatment ( $1 \mathrm{~g} /$ day) for 2 months, using metformin therapy $(1.5 \mathrm{~g} /$ day) and rosiglitazone group ( $4 \mathrm{mg} / \mathrm{b} . \mathrm{i} . \mathrm{d})$ as reference groups. Blood samples were taking before and after treatments to measure $\mathrm{FBG}, \mathrm{HbA}_{1 \mathrm{c}}$, triglyceride, and serum insulin levels. Compared to values prior to treatment, berberine significantly lowered FBG by 25.9\% $(P<0.001), \mathrm{HbA}_{1 \mathrm{c}}$ by $18.1 \%$ $(P<0.00)$, and triglycerides by $17.6 \%(P<0.01)$. The hypoglycaemic effects of berberine were comparable to metformin and rosiglitazone. Serum insulin level was declined significantly $(P<0.01)$ by $28.2 \%$; this indicates increased insulin sensitivity in peripheral tissues by berberine treatment. Peripheral blood lymphocytes from berberine treated patients were isolated to examine the InsR expression. The surface expression of InsR significantly elevated by 3.6-fold after berberine treatment.

Metformin and rosiglitazone are not recommended for use in diabetic patients with liver function damage [54, 63]. So the effect of berberine was tested in hyperglycaemic patients with hepatitis. Hepatitis $\mathrm{B}$ and $\mathrm{C}$ patients with hyperglycaemia received berberine at $1 \mathrm{~g}$ /day for 2 months. In both diabetic hepatitis $\mathrm{B}$ and $\mathrm{C}$ patients, berberine significantly reduced FBG and triglyceride levels. Berberine treatment also reduced the elevated alanine transaminase and aspartate aminotransferase levels in these patients. Overall, berberine is safe and effective in hyperglycaemic patients with liver function damage.

Table 6 compares clinical studies of berberine in diabetes patients. Across the studies, berberine has shown to significantly reduce $\mathrm{FBG}, \mathrm{PBG}$, and $\mathrm{HbA}_{1 \mathrm{c}}$ levels. Berberine also demonstrated ability to reduce triglyceride and cholesterol levels. Minimal gastrointestinal side effects were shown but no liver or kidney damage was observed. These observations in diabetes patients demonstrate that berberine is a safe and effective antidiabetic agent.

\section{Discussion}

The "rule-of-five" analysis by Lipinski et al. [7] shows that poor absorption or permeation of a compound is more likely when there are more than five hydrogen-bond donors; the molecular mass is more than $500 \mathrm{Da}$; the lipophilicity is high (expressed as $c \log P>5$ ); the sum of nitrogen and oxygen is more than 10. Specific structural and physiochemical properties, such as "rule-of-five," are required for clinical drugs to have sufficient levels of efficacy, bioavailability, and safety, which define target sites to which drug-like molecules can bind [4].

Plant compounds exhibit enormous structural diversity and only a small portion of the diversity has been explored for its pharmacological potential [64]. In recent years, herbal compounds have been source of new drugs [64]. Approximately $28 \%$ of new molecular entities (NMEs) between 1981 and 2002 were natural products or natural product derived; further to this, $20 \%$ of these NMEs were natural product mimics [65]. There are a number of successful plantderived drugs, especially in anti-cancer treatment. Medicinal herbal compounds have become an important source for the discovery of new drugs. Further, drugs derived from medicinal plants can also be used as drug leads suitable for optimization by medicinal and synthetic chemists [65].

As Chinese herbal medicine becomes increasingly popular in the west, researchers are spending more time looking into mechanisms of actions of crude extracts and herbal compounds such as berberine. In recent years, extensive research has been done to explore the effects of berberine on various cell lines in vitro. In cell-based studies, berberine has shown effects on multiple molecular targets and alters various biological pathways. Berberine associates with a range of conditions, particularly diabetes, hyperlipidemia, and cancer. Many in vitro studies showed potent anticancer properties of berberine against various cancer cells. This observation is valuable in the search for new anti-cancer therapeutics with potent anti-cancer effects but reduced side effect. So berberine may potentially be developed into an anticancer agent, like other natural compounds (taxol, camptothecin) that have been developed and used as anticancer agents.

Diabetes mellitus is a major health problem around the world and its prevalence is on the rise. Diabetes mellitus drug therapy is limited by availability of effective medications, as existing oral hypoglycaemic agents often have side effects and fails in long-term administration [14]. Berberine has shown significant results in fasting blood glucose levels reduction, increase in insulin sensitivity, and improvement in insulin resistance in vitro, in diabetic animal models and in diabetic patients. Further, berberine shows mechanism that current antidiabetic drugs do not have. For instance, berberine has shown effects on pancreatic $\beta$-cell number and mass improvement $[41,50,51]$. In addition, berberine has a good safety profile and does not show side effects such as hypoglycaemia, weight gain, or liver and kidney damage. Metformin and rosiglitazone are not recommended for use in diabetic patients with liver function damage $[54,63]$. Berberine has shown to be effective in the reduction of blood glucose level and is safe in diabetic patients with 
TABLE 6: Comparison of clinical studies of berberine in diabetes patients.

\begin{tabular}{|c|c|c|c|c|c|c|}
\hline Study type & Study subjects & Berberine dosage & Control treatment & Major findings & Side effects & Reference \\
\hline $\begin{array}{l}\text { Randomised, } \\
\text { double-blind, } \\
\text { placebo-controlled, } \\
\text { multiple-center }\end{array}$ & $\begin{array}{l}\text { Type } 2 \text { diabetes } \\
\text { and } \\
\text { dyslipidemia } \\
(n=116)\end{array}$ & $\begin{array}{l}0.5 \mathrm{~g} \text {, b.i.d for } 3 \\
\text { months }\end{array}$ & Placebo & $\begin{array}{l}\text { Significantly reduced } \\
\text { fasting and postload } \\
\text { plasma glucose, } \mathrm{HbA}_{\mathrm{lc}} \\
\text { Significantly reduced } \\
\text { triglyceride, total } \\
\text { cholesterol, and } \\
\text { LDL-cholesterol }\end{array}$ & $\begin{array}{l}\text { Mild to moderate } \\
\text { constipation in } 5 \\
\text { patients }\end{array}$ & {$[61]$} \\
\hline \multirow[b]{2}{*}{$\begin{array}{l}\text { Randomised, blinded, } \\
\text { placebo-controlled }\end{array}$} & $\begin{array}{l}\text { Type } 2 \text { diabetes } \\
(n=36)\end{array}$ & $\begin{array}{l}0.5 \mathrm{~g} \text {, t.i.d for } 3 \\
\text { months }\end{array}$ & $\begin{array}{l}\text { Metformin }(0.5 \mathrm{~g} \\
\text { t.i.d) }\end{array}$ & $\begin{array}{l}\text { Significantly reduced } \\
\text { FBG, } \mathrm{PBG} \text {, and } \mathrm{HbA}_{\mathrm{lc}} \\
\text { Significantly reduced } \\
\text { plasma triglycerides }\end{array}$ & \multirow[b]{2}{*}{$\begin{array}{l}\text { Transient } \\
\text { gastrointestinal } \\
\text { adverse effects. No } \\
\text { liver or kidney } \\
\text { damage }\end{array}$} & \multirow[b]{2}{*}[14]{} \\
\hline & $\begin{array}{l}\text { Type } 2 \text { diabetes } \\
\text { poorly } \\
\text { controlled } \\
(n=48)\end{array}$ & $\begin{array}{l}0.5 \mathrm{~g} \text {, t.i.d for } 3 \\
\text { months }\end{array}$ & $\begin{array}{l}\text { Existing } \\
\text { anti-diabetic } \\
\text { treatment }\end{array}$ & $\begin{array}{l}\text { Lowered FBG and PBG } \\
\text { Significantly decreased } \\
\mathrm{HbA}_{1 \mathrm{lc}} \\
\text { Significantly reduced } \\
\text { fasting plasma insulin } \\
\text { and HOMA-IR }\end{array}$ & & \\
\hline \multirow[t]{2}{*}{ Randomised } & $\begin{array}{l}\text { Type } 2 \text { diabetes } \\
(n=97)\end{array}$ & $\begin{array}{l}1 \mathrm{~g} / \text { day for } 2 \\
\text { months }\end{array}$ & $\begin{array}{l}\text { Metformin } \\
(1.5 \mathrm{~g} / \text { day }) ; \\
\text { rosiglitazone } \\
(4 \mathrm{mg} / \text { day })\end{array}$ & $\begin{array}{l}\text { Significantly reduced } \\
\text { FBG } \mathrm{HbA}_{\mathrm{lc}} \text {, and } \\
\text { triglycerides } \\
\text { Serum insulin level was } \\
\text { declined significantly } \\
(P<0.01) \text {, increased } \\
\text { insulin sensitivity in } \\
\text { peripheral tissues. } \\
\text { Significantly elevated } \\
\text { surface expression of } \\
\text { InsR by 3.6-fold }\end{array}$ & No adverse events & \multirow[t]{2}{*}[62]{} \\
\hline & $\begin{array}{l}\text { Type } 2 \text { diabetes } \\
\text { with chronic } \\
\text { hepatitis } \mathrm{C} \text { virus } \\
\text { infection } \\
(n=35)\end{array}$ & $\begin{array}{l}1 \mathrm{~g} / \text { day for } 2 \\
\text { months }\end{array}$ & N/A & $\begin{array}{l}\text { Significantly reduced } \\
\text { FBG and triglyceride } \\
\text { levels } \\
\text { Reduced the elevated } \\
\text { ALT and aspartate } \\
\text { aminotransferase levels }\end{array}$ & & \\
\hline
\end{tabular}

b.i.d: twice daily; t.i.d: three times daily; FBG: fasting blood glucose; HOMA-IR: homeostasis model of assessment-insulin resistance; PBG: postprandial blood glucose.

viral hepatitis [62]. Berberine can therefore be investigated as an effective diabetes therapy with patients with liver function damage. In addition to its hypoglycemic effects in diabetic patients, berberine also reduced triglyceride and cholesterol levels. Abnormalities in lipid metabolism often deteriorate diabetes and cause complications. The regulation of lipid metabolism in diabetes patients by berberine may have clinical significance in managing diabetic patients with hyperlipidemia. Although there are only a small number of clinical studies and evidence is limited, current reports still show a promising future for berberine being developed into a new antidiabetic agent.

In China, berberine has been manufactured into the over-the-counter drug Huang Lian Su Pian, also known as Coptis Extract Tablets for the treatment of traveler's diarrhea $[14,17]$. However, in vitro and in vivo studies have shown that berberine has potent anti-cancer, antidiabetic, antilipidemic, and anti-inflammatory effects. Therefore, further clinical studies are warranted to investigate the potential of berberine in the application of cancer and diabetes treatments in the future.

Pharmacological activity of CHMs begins with the binding of the active components to their molecular targets. CHMs are considered as typical multitherapeutics that can interact simultaneously with multiple targets. The origins and the progression of diseases are multifactorial. Complex disorders such as cancer, cardiovascular disease, and depression tend to result from multiple molecular abnormalities, not from a single defect [66]. Biochemical and genetic studies revealed the molecular mechanism that underlie common illnesses [66]. Reports show that targets for neoplasm diseases, circulatory system diseases, infectious diseases, and nervous 
system and sense organs disorders constitute the largest number of targets [1]. Because drug targets are presented at the molecular level, increased knowledge of herbal targets can facilitate deeper understanding of complex diseases at its fundamental level. In turn, it is likely to determine the optimal molecular targets for therapeutic intervention [6].

Further to assisting the molecular dissection of the mechanism of action of CHMs, knowledge on herbal targets makes it possible to use disease specific targets and design more desirable herbal drugs/formulas with increased specificity and efficacy. Target-oriented synthesis in drug discovery involves in preselected protein targets [67]. Binding of drugs to preselected protein target/s is dependent on which biological pathway the drug is aimed to modulate the target or the diseased pathway(s) [67]. Target and disease specific drug design results in improved efficacy and reduced side effects, especially in high impact diseases that require more effective and more treatment options. However, due to the fact that diseases often involve in multiple molecular abnormalities, diversity-oriented syntheses are used in efforts to identify simultaneously therapeutic protein targets and their small-molecule regulators [67]. Target-oriented drug design allows more focused drug design, which in turn costs less time and money for pharmaceutical companies.

Protein structure of well-validated old and new targets should be able to guide the chemical effort directed at new drugs [68]. Study of various aspects of known targets including molecular mechanism of their binding agents and related adverse effects is useful for finding clues to new target identification [9]. Based on the knowledge of molecular targets and molecular understanding of disease state and using this knowledge will allow some direction in identifying potential targets. Potential herbal targets may come from the same class as confirmed therapeutic targets and have similar physiological functions, or maybe a structure along a biological pathway. Additionally, with increased number of potential targets from $\sim 500$ to $>5,000$, the nature of pharmaceutical research has changed. This increase in numbers has given researchers more opportunities to discover and design new and improved drugs.

Target selection may be one of the most important determinants of attrition and the overall R\&D productivity. There are few ways to overcome this challenge and improve the target selection process, in turn, improving R\&D productivity. First of all, researchers can discover new target classes. Targets of herbal medicine are becoming a popular resource to find new target classes. In addition, increased understanding of genetic variations/polymorphisms of drug targets or drug metabolising enzymes can assist in target selection and drug metabolism. Further, the use of new technology can help to speed up the early exploratory discovery phase of drug discovery.

In summary, updated knowledge of herbal targets is valuable contribution to complex disease understanding and clinical responses. Further, drug discovery and development from herbal medicines can be supported by new target discovery and target-focused drug design. This will speed up the exploratory phase of drug R\&D and benefit the pharmaceutical industry in terms of cost and time.

\section{Abbreviations}

Bax: BCL2-associated X protein

FBG: Fasting blood glucose

GLP-1: Glucagon like peptide 1

$\mathrm{HbA}_{1 \mathrm{c}}$ : Hemoglobin $\mathrm{A}_{\mathrm{lc}}$

InsR: Insulin receptor

PBG: Postprandial blood glucose.

\section{Authors' Contribution}

Xiao-Wu Chen and Yuan Ming Di contributed equally to this work.

\section{References}

[1] C. J. Zheng, L. Y. Han, C. W. Yap, B. Xie, and Y. Z. Chen, "Trends in exploration of therapeutic targets," Drug News and Perspectives, vol. 18, no. 2, pp. 109-127, 2005.

[2] B. Bryant and K. Knights, Pharmacology for Health Professionals, Mosby Elsevier, Chatswood, Australia, 3rd edition, 2011.

[3] A. L. Hopkins and C. R. Groom, "The druggable genome," Nature Reviews Drug Discovery, vol. 1, no. 9, pp. 727-730, 2002.

[4] C. J. Zheng, L. Y. Han, C. W. Yap, Z. L. Ji, Z. W. Cao, and Y. Z. Chen, "Therapeutic targets: progress of their exploration and investigation of their characteristics," Pharmacological Reviews, vol. 58, no. 2, pp. 259-279, 2006.

[5] J. Drews, "Genomic sciences and the medicine of tomorrow," Nature Biotechnology, vol. 14, no. 11, pp. 1516-1518, 1996.

[6] J. Drews and S. Ryser, "The role of innovation in drug development," Nature Biotechnology, vol. 15, no. 13, pp. 13181319, 1997.

[7] C. A. Lipinski, F. Lombardo, B. W. Dominy, and P. J. Feeney, "Experimental and computational approaches to estimate solubility and permeability in drug discovery and development settings," Advanced Drug Delivery Reviews, vol. 46, no. 1-3, pp. 3-26, 2001.

[8] X. Chen, C. J. Zheng, L. Y. Han, B. Xie, and Y. Z. Chen, "Trends in the exploration of therapeutic targets for the treatment of endocrine, metabolic and immune disorders," Endocrine, Metabolic and Immune Disorders, vol. 7, no. 3, pp. 225-231, 2007.

[9] X. Chen, Z. L. Ji, and Y. Z. Chen, "TTD: therapeutic target database," Nucleic Acids Research, vol. 30, no. 1, pp. 412-415, 2002.

[10] J. Qiu, "Traditional medicine: a culture in the balance," Nature, vol. 448, no. 7150, pp. 126-128, 2007.

[11] R. Stone, "Biochemistry: lifting the veil on traditional Chinese medicine," Science, vol. 319, no. 5864, pp. 709-710, 2008.

[12] P. Barnes, E. Powell-Griner, K. McFann, and R. Nahin, “Complementary and alternative medicine use among adults: United States, 2002," Advanced Data From Vital and Health Statistics 343, National Center for Health Statistics, Hyattsville, Md, USA.

[13] E. Ernst and M. H. Pittler, "Herbal medicine," Medical Clinics of North America, vol. 86, no. 1, pp. 149-161, 2002.

[14] J. Yin, H. Xing, and J. Ye, "Efficacy of berberine in patients with type 2 diabetes mellitus," Metabolism: Clinical and Experimental, vol. 57, no. 5, pp. 712-717, 2008.

[15] L. Grycová, J. Dostál, and R. Marek, "Quaternary protoberberine alkaloids," Phytochemistry, vol. 68, no. 2, pp. 150-175, 2007. 
[16] W. Xie and L. Du, "Diabetes is an inflammatory disease: evidence from traditional Chinese medicines," Diabetes, Obesity and Metabolism, vol. 13, no. 4, pp. 289-301, 2011.

[17] B. Schoenbart and S. Ellen, "Traditional Chinese Medicine for the Digestive System," 2007, http://health.howstuffworks .com/wellness/natural-medicine/chinese/traditional-chinese-medicine-for-the-digestive-system.htm.

[18] Y. T. Ho, C. C. Lu, J. S. Yang et al., "Berberine induced apoptosis via promoting the expression of caspase- $8,-9$ and -3 , apoptosis-inducing factor and endonuclease G in SCC-4 human tongue squamous carcinoma cancer cells," Anticancer Research, vol. 29, no. 10, pp. 4063-4070, 2009.

[19] W. H. Hsu, Y. S. Hsieh, H. C. Kuo et al., "Berberine induces apoptosis in SW620 human colonic carcinoma cells through generation of reactive oxygen species and activation of JNK/p38 MAPK and FasL," Archives of Toxicology, vol. 81, no. 10, pp. 719-728, 2007.

[20] S. K. Katiyar, S. M. Meeran, N. Katiyar, and S. Akhtar, "P53 cooperates berberine-induced growth inhibition and apoptosis of non-small cell human lung cancer cells in vitro and tumor xenograft growth in vivo," Molecular Carcinogenesis, vol. 48, no. 1, pp. 24-37, 2009.

[21] S. K. Mantena, S. D. Sharma, and S. K. Katiyar, "Berberine inhibits growth, induces G1 arrest and apoptosis in human epidermoid carcinoma A431 cells by regulating CdkiCdk-cyclin cascade, disruption of mitochondrial membrane potential and cleavage of caspase 3 and PARP," Carcinogenesis, vol. 27, no. 10, pp. 2018-2027, 2006.

[22] K. K. W. Auyeung and J. K. S. Ko, "Coptis chinensis inhibits hepatocellular carcinoma cell growth through nonsteroidal anti-inflammatory drug-activated gene activation," International Journal of Molecular Medicine, vol. 24, no. 4, pp. 571$577,2009$.

[23] K. Inoue, U. Kulsum, S. A. Chowdhury et al., "Tumor-specific cytotoxicity and apoptosis-inducing activity of berberines," Anticancer Research, vol. 25, no. 6, pp. 4053-4059, 2005.

[24] J. P. Lin, J. S. Yang, J. H. Lee, W. T. Hsieh, and J. G. Chung, "Berberine induces cell cycle arrest and apoptosis in human gastric carcinoma SNU-5 cell line," World Journal of Gastroenterology, vol. 12, no. 1, pp. 21-28, 2006.

[25] M. S. Choi, D. Y. Yuk, J. H. Oh et al., "Berberine inhibits human neuroblastoma cell growth through induction of p53dependent apoptosis," Anticancer Research, vol. 28, no. 6, pp. 3777-3784, 2008.

[26] F. Tang, D. Wang, C. Duan et al., "Berberine inhibits metastasis of nasopharyngeal carcinoma $5-8 \mathrm{~F}$ cells by targeting rho kinase-mediated ezrin phosphorylation at threonine 567," Journal of Biological Chemistry, vol. 284, no. 40, pp. 2745627466, 2009.

[27] K. Fukuda, Y. Hibiya, M. Mutoh, M. Koshiji, S. Akao, and H. Fujiwara, "Inhibition by berberine of cyclooxygenase-2 transcriptional activity in human colon cancer cells," Journal of Ethnopharmacology, vol. 66, no. 2, pp. 227-233, 1999.

[28] J. G. Chung, G. W. Chen, C. F. Hung et al., "Effects of berberine on arylamine $\mathrm{N}$-acetyltransferase activity and 2aminofluorene-DNA adduct formation in human leukemia cells," American Journal of Chinese Medicine, vol. 28, no. 2, pp. 227-238, 2000.

[29] M. S. Choi, J. H. Oh, S. M. Kim et al., "Berberine inhibits p53-dependent cell growth through induction of apoptosis of prostate cancer cells," International Journal of Oncology, vol. 34, no. 5, pp. 1221-1230, 2009.

[30] S. K. Mantena, S. D. Sharma, and S. K. Katiyar, "Berberine, a natural product, induces G1-phase cell cycle arrest and caspase-3-dependent apoptosis in human prostate carcinoma cells," Molecular Cancer Therapeutics, vol. 5, no. 2, pp. 296-308, 2006.

[31] C. C. Lin, S. T. Kao, G. W. Chen, H. C. Ho, and J. G. Chung, "Apoptosis of human leukemia HL-60 cells and murine leukemia WEHI-3 cells induced by berberine through the activation of caspase-3," Anticancer Research, vol. 26, no. 1, pp. 227-242, 2006.

[32] Y. Luo, Y. Hao, T. P. Shi, W. W. Deng, and N. Li, "Berberine inhibits cyclin D1 expression via suppressed binding of AP-1 transcription factors to CCND1 AP-1 motif," Acta Pharmacologica Sinica, vol. 29, no. 5, pp. 628-633, 2008.

[33] S. Jantova, L. Cipak, and S. Letasiova, "Berberine induces apoptosis through a mitochondrial/caspase pathway in human promonocytic U937 cells," Toxicology in Vitro, vol. 21, no. 1, pp. 25-31, 2007.

[34] Y. T. Ho, J. S. Yang, T. C. Li et al., "Berberine suppresses in vitro migration and invasion of human SCC-4 tongue squamous cancer cells through the inhibitions of FAK, IKK, NF- $\kappa$ B, u-PA and MMP-2 and -9," Cancer Letters, vol. 279, no. 2, pp. 155-162, 2009.

[35] H. Li, L. Guo, S. Jie et al., "Berberine inhibits SDF-1-induced AML cells and leukemic stem cells migration via regulation of SDF-1 level in bone marrow stromal cells," Biomedicine and Pharmacotherapy, vol. 62, no. 9, pp. 573-578, 2008.

[36] G. C. M. Bruschi, C. C. De Souza, M. R. V. Z. K. Fagundes et al., "Sensitivity to camptothecin in Aspergillus nidulans identifies a novel gene, $\mathrm{scaA}^{+}$, related to the cellular DNA damage response," Molecular and General Genetics, vol. 265, no. 2, pp. 264-275, 2001.

[37] Y. Chen, Y. Li, Y. Wang, Y. Wen, and C. Sun, "Berberine improves free-fatty-acid-induced insulin resistance in L6 myotubes through inhibiting peroxisome proliferator-activated receptor $\gamma$ and fatty acid transferase expressions," Metabolism: Clinical and Experimental, vol. 58, no. 12, pp. 1694-1702, 2009.

[38] W. J. Kong, H. Zhang, D. Q. Song et al., "Berberine reduces insulin resistance through protein kinase C-dependent upregulation of insulin receptor expression," Metabolism: Clinical and Experimental, vol. 58, no. 1, pp. 109-119, 2009.

[39] G. Y. Pan, Z. J. Huang, G. J. Wang et al., "The antihyperglycaemic activity of berberine arises from a decrease of glucose absorption," Planta Medica, vol. 69, no. 7, pp. 632-636, 2003.

[40] Z. S. Wang, F. E. Lu, L. J. Xu, and H. Dong, "Berberine reduces endoplasmic reticulum stress and improves insulin signal transduction in Hep G2 cells," Acta Pharmacologica Sinica, vol. 31, no. 5, pp. 578-584, 2010.

[41] Y. Yu, L. Liu, X. Wang et al., "Modulation of glucagon-like peptide-1 release by berberine: in vivo and in vitro studies," Biochemical Pharmacology, vol. 79, no. 7, pp. 1000-1006, 2010.

[42] J. Yu, B. K. Piao, Y. X. Pei, X. Qi, and B. J. Hua, "Protective effects of tetrahydropalmatine against $\gamma$-radiation induced damage to human endothelial cells," Life Sciences, vol. 87, no. 1-2, pp. 55-63, 2010.

[43] L. Liu, Y. L. Yu, J. S. Yang et al., "Berberine suppresses intestinal disaccharidases with beneficial metabolic effects in diabetic states, evidences from in vivo and in vitro study," Naunyn-Schmiedeberg's Archives of Pharmacology, vol. 381, no. 4, pp. 371-381, 2010.

[44] L. Q. Tang, W. Wei, L. M. Chen, and S. Liu, "Effects of berberine on diabetes induced by alloxan and a high-fat/highcholesterol diet in rats," Journal of Ethnopharmacology, vol. 108, no. 1, pp. 109-115, 2006. 
[45] C. Wang, J. Li, X. Lv et al., "Ameliorative effect of berberine on endothelial dysfunction in diabetic rats induced by highfat diet and streptozotocin," European Journal of Pharmacology, vol. 620, no. 1-3, pp. 131-137, 2009.

[46] X. Xia, J. Yan, Y. Shen et al., "Berberine improves glucose metabolism in diabetic rats by inhibition of hepatic gluconeogenesis," PLoS ONE, vol. 6, no. 2, Article ID e16556, 2011.

[47] B. L. Wajchenberg, " $\beta$-cell failure in diabetes and preservation by clinical treatment," Endocrine Reviews, vol. 28, no. 2, pp. 187-218, 2007.

[48] D. Giugliano, E. Standl, T. Vilsbøll et al., "Is the current therapeutic armamentarium in diabetes enough to control the epidemic and its consequences? What are the current shortcomings?" Acta Diabetologica, vol. 46, no. 3, pp. 173181, 2009.

[49] R. J. Heine, M. Diamant, J. C. Mbanya, and D. M. Nathan, "Management of hyperglycaemia in type 2 diabetes," British Medical Journal, vol. 333, no. 7580, pp. 1200-1204, 2006.

[50] S. S. Lu, Y. L. Yu, H. J. Zhu et al., "Berberine promotes glucagon-like peptide-1 (7-36) amide secretion in streptozotocin-induced diabetic rats," Journal of Endocrinology, vol. 200, no. 2, pp. 159-165, 2009.

[51] J. Zhou, S. Zhou, J. Tang et al., "Protective effect of berberine on beta cells in streptozotocin- and high-carbohydrate/highfat diet-induced diabetic rats," European Journal of Pharmacology, vol. 606, no. 1-3, pp. 262-268, 2009.

[52] J. Hone, D. Accili, L. I. Al-Gazali, G. Lestringant, T. Orban, and S. I. Taylor, "Homozygosity for a new mutation (Ile119 $\rightarrow$ Met) in the insulin receptor gene in five sibs with familial insulin resistance," Journal of Medical Genetics, vol. 31, no. 9, pp. 715-716, 1994.

[53] J. J. Holst, "The physiology of glucagon-like peptide 1," Physiological Reviews, vol. 87, no. 4, pp. 1409-1439, 2007.

[54] Y. S. Lee, W. S. Kim, K. H. Kim et al., "Berberine, a natural plant product, activates AMP-activated protein kinase with beneficial metabolic effects in diabetic and insulin-resistant states," Diabetes, vol. 55, no. 8, pp. 2256-2264, 2006.

[55] S. H. Leng, F. E. Lu, and L. J. Xu, "Therapeutic effects of berberine in impaired glucose tolerance rats and its influence on insulin secretion," Acta Pharmacologica Sinica, vol. 25, no. 4, pp. 496-502, 2004.

[56] Y. Wang, T. Campbell, B. Perry, C. Beaurepaire, and L. Qin, "Hypoglycemic and insulin-sensitizing effects of berberine in high-fat diet- and streptozotocin-induced diabetic rats," Metabolism: Clinical and Experimental, vol. 60, no. 2, pp. 298-305, 2011.

[57] S. F. Dong, Y. Hong, M. Liu et al., "Berberine attenuates cardiac dysfunction in hyperglycemic and hypercholesterolemic rats," European Journal of Pharmacology, vol. 660, no. 2-3, pp. 368-374, 2011.

[58] J. Y. Zhou, S. W. Zhou, K. B. Zhang et al., "Chronic effects of berberine on blood, liver glucolipid metabolism and liver PPARs expression in diabetic hyperlipidemic rats," Biological and Pharmaceutical Bulletin, vol. 31, no. 6, pp. 1169-1176, 2008.

[59] X. Chang, H. Yan, J. Fei et al., "Berberine reduces methylation of the MTTP promoter and alleviates fatty liver induced by a high-fat diet in rats," Journal of Lipid Research, vol. 51, no. 9, pp. 2504-2515, 2010.

[60] S. Manley, "Haemoglobin A1c—a marker for complications of type 2 diabetes: the experience from the UK Prospective Diabetes Study (UKPDS)," Clinical Chemistry and Laboratory Medicine, vol. 41, no. 9, pp. 1182-1190, 2003.
[61] Y. Zhang, X. Li, D. Zou et al., "Treatment of type 2 diabetes and dyslipidemia with the natural plant alkaloid berberine," The Journal of Clinical Endocrinology \& Metabolism, vol. 93, pp. 2559-2565, 2008.

[62] H. Zhang, J. Wei, R. Xue et al., "Berberine lowers blood glucose in type 2 diabetes mellitus patients through increasing insulin receptor expression," Metabolism: Clinical and Experimental, vol. 59, no. 2, pp. 285-292, 2010.

[63] A. Emslie-Smith, D. I. R. Boyle, J. M. M. Evans, F. Sullivan, and A. D. Morris, "Contraindications to metformin therapy in patients with type 2 diabetes - a population-based study of adherence to prescribing guidelines," Diabetic Medicine, vol. 18, no. 6, pp. 483-488, 2001.

[64] T. M. Ehrman, D. J. Barlow, and P. J. Hylands, "Phytochemical databases of Chinese herbal constituents and bioactive plant compounds with known target specificities," Journal of Chemical Information and Modeling, vol. 47, no. 2, pp. 254263, 2007.

[65] D. J. Newman, G. M. Cragg, and K. M. Snader, "Natural products as sources of new drugs over the period 1981-2002," Journal of Natural Products, vol. 66, no. 7, pp. 1022-1037, 2003.

[66] S. Frantz, "Playing dirty," Nature, vol. 437, no. 7061, pp. $942-$ 943, 2005.

[67] S. L. Schreiber, "Target-oriented and diversity-oriented organic synthesis in drug discovery," Science, vol. 287, no. 5460, pp. 1964-1969, 2000.

[68] J. Drews, "Drug discovery: a historical perspective," Science, vol. 287, no. 5460, pp. 1960-1964, 2000.

[69] J. L. Gao, J. M. Shi, S. M. Y. Lee, Q. W. Zhang, and Y. T. Wang, "Angiogenic pathway inhibition of Corydalis yanhusuo and berberine in human umbilical vein endothelial cells," Oncology Research, vol. 17, no. 11-12, pp. 519-526, 2009.

[70] J. P. Lin, J. S. Yang, C. C. Wu et al., "Berberine induced downregulation of matrix metalloproteinase-1, -2 and -9 in human gastric cancer cells (SNU-5) in vitro," In Vivo, vol. 22, no. 2, pp. 223-230, 2008.

[71] T. H. Lin, H. C. Kuo, F. P. Chou, and F. J. Lu, "Berberine enhances inhibition of glioma tumor cell migration and invasiveness mediated by arsenic trioxide," BMC Cancer, vol. 8, article 58, 2008.

[72] P. L. Peng, Y. S. Hsieh, C. J. Wang, J. L. Hsu, and F. P. Chou, "Inhibitory effect of berberine on the invasion of human lung cancer cells via decreased productions of urokinaseplasminogen activator and matrix metalloproteinase-2," Toxicology and Applied Pharmacology, vol. 214, no. 1, pp. 8-15, 2006.

[73] J. M. Brusq, N. Ancellin, P. Grondin et al., "Inhibition of lipid synthesis through activation of AMP kinase: an additional mechanism for the hypolipidemic effects of berberine," Journal of Lipid Research, vol. 47, no. 6, pp. 1281-1288, 2006.

[74] C. W. Chi, Y. F. Chang, T. W. Chao et al., "Flowcytometric analysis of the effect of berberine on the expression of glucocorticoid receptors in human hepatoma HepG2 cells," Life Sciences, vol. 54, no. 26, pp. 2099-2107, 1994.

[75] M. Asai, N. Iwata, A. Yoshikawa et al., "Berberine alters the processing of Alzheimer's amyloid precursor protein to decrease $\mathrm{A} \beta$ secretion," Biochemical and Biophysical Research Communications, vol. 352, no. 2, pp. 498-502, 2007.

[76] J. M. Hwang, H. C. Kuo, T. H. Tseng, J. Y. Liu, and C. Y. Chu, "Berberine induces apoptosis through a mitochondria/caspases pathway in human hepatoma cells," Archives of Toxicology, vol. 80, no. 2, pp. 62-73, 2006. 
[77] M. K. Pandey, B. Sung, A. B. Kunnumakkara, G. Sethi, M. M. Chaturvedi, and B. B. Aggarwal, "Berberine modifies cysteine 179 of $\mathrm{I} \kappa \mathrm{B} \alpha$ kinase, suppresses nuclear factor- $\kappa \mathrm{B}$-regulated antiapoptotic gene products, and potentiates apoptosis," Cancer Research, vol. 68, no. 13, pp. 5370-5379, 2008.

[78] C. C. Lin, L. T. Ng, F. F. Hsu, D. E. Shieh, and L. C. Chiang, "Cytotoxic effects of Coptis chinensis and Epimedium sagittatum extracts and their major constituents (berberine, coptisine and icariin) on hepatoma and leukaemia cell growth," Clinical and Experimental Pharmacology and Physiology, vol. 31, no. 1-2, pp. 65-69, 2004.

[79] J. G. Lin, J. G. Chung, L. T. Wu, G. W. Chen, H. L. Chang, and T. F. Wang, "Effects of berberine on arylamine n-acetyltransferase activity in human colon tumor cells," American Journal of Chinese Medicine, vol. 27, no. 2, pp. 265275, 1999.

[80] D. Y. Wang, C. C. Yeh, J. H. Lee, C. F. Hung, and J. G. Chung, "Berberine inhibited arylamine $\mathrm{N}$-acetyltransferase activity and gene expression and DNA adduct formation in human malignant astrocytoma (G9T/VGH) and brain glioblastoma multiforms (GBM 8401) cells," Neurochemical Research, vol. 27, no. 9, pp. 883-889, 2002.

[81] J. B. Kim, E. Ko, W. Han, I. Shin, S. Y. Park, and D. Y. Non, "Berberine diminishes the side population and ABCG2 transporter expression in MCF-7 breast cancer cells," Planta Medica, vol. 74, no. 14, pp. 1693-1700, 2008.

[82] J. Liu, C. He, K. Zhou, J. Wang, and J. X. Kang, "Coptis extracts enhance the anticancer effect of estrogen receptor antagonists on human breast cancer cells," Biochemical and Biophysical Research Communications, vol. 378, no. 2, pp. 174-178, 2009.

[83] X. H. Wang, S. M. Jiang, and Q. W. Sun, "Effects of berberine on human rheumatoid arthritis fibroblast-like synoviocytes," Experimental Biology and Medicine, vol. 236, no. 7, pp. 859866, 2011.

[84] C. C. Lin, S. Y. Lin, J. G. Chung, J. P. Lin, G. W. Chen, and S. T. Kao, "Down-regulation of cyclin B1 and Up-regulation of Wee1 by berberine promotes entry of leukemia cells into the G2/M-phase of the cell cycle," Anticancer Research, vol. 26, no. 2, pp. 1097-1104, 2006.

[85] J. P. Lin, J. S. Yang, N. W. Chang et al., "GADD153 mediates berberine-induced apoptosis in human cervical cancer $\mathrm{Ca}$ ski cells," Anticancer Research, vol. 27, no. 5, pp. 3379-3386, 2007.

[86] Y. T. Ho, J. S. Yang, C. C. Lu et al., "Berberine inhibits human tongue squamous carcinoma cancer tumor growth in a murine xenograft model," Phytomedicine, vol. 16, no. 9, pp. 887-890, 2009.

[87] S. M. Meeran, S. Katiyar, and S. K. Katiyar, "Berberineinduced apoptosis in human prostate cancer cells is initiated by reactive oxygen species generation," Toxicology and Applied Pharmacology, vol. 229, no. 1, pp. 33-43, 2008.

[88] S. Nishida, S. Kikuichi, S. Yoshioka et al., "Induction of apoptosis in HL-60 cells treated with medicinal herbs," American Journal of Chinese Medicine, vol. 31, no. 4, pp. 551562, 2003.

[89] K. Yan, C. Zhang, J. Feng et al., "Induction of G1 cell cycle arrest and apoptosis by berberine in bladder cancer cells," European Journal of Pharmacology, vol. 661, no. 1-3, pp. 17, 2011.

[90] K. S. Eom, J. M. Hong, M. J. Youn et al., "Berberine induces G1 arrest and apoptosis in human glioblastoma T98G cells through mitochondrial/caspases pathway," Biological and Pharmaceutical Bulletin, vol. 31, no. 4, pp. 558-562, 2008.
[91] C. M. Tsang, E. P. W. Lau, K. Di et al., "Berberine inhibits Rho GTPases and cell migration at low doses but induces G2 arrest and apoptosis at high doses in human cancer cells," International Journal of Molecular Medicine, vol. 24, no. 1, pp. 131-138, 2009.

[92] Z. Liu, Q. Liu, B. Xu et al., "Berberine induces p53-dependent cell cycle arrest and apoptosis of human osteosarcoma cells by inflicting DNA damage," Mutation Research, vol. 662, no. 1-2, pp. 75-83, 2009.

[93] H. S. Cui, S. Hayasaka, X. Y. Zhang, Y. Hayasaka, Z. L. Chi, and L. S. Zheng, "Effect of berberine on interleukin 8 and monocyte chemotactic protein 1 expression in a human retinal pigment epithelial cell line," Ophthalmic Research, vol. 38, no. 3, pp. 149-157, 2006.

[94] R. Piyanuch, M. Sukhthankar, G. Wandee, and S. J. Baek, "Berberine, a natural isoquinoline alkaloid, induces NAG-1 and ATF3 expression in human colorectal cancer cells," Cancer Letters, vol. 258, no. 2, pp. 230-240, 2007.

[95] M. Khan, B. Giessrigl, C. Vonach et al., "Berberine and a Berberis lycium extract inactivate Cdc25A and induce $\alpha$-tubulin acetylation that correlate with HL-60 cell cycle inhibition and apoptosis," Mutation Research, vol. 683, no. 1-2, pp. 123-130, 2010.

[96] P. Chatterjee and M. R. Franklin, "Human cytochrome P450 inhibition and metabolic-intermediate complex formation by goldenseal extract and its methylenedioxyphenyl components," Drug Metabolism and Disposition, vol. 31, no. 11, pp. 1391-1397, 2003.

[97] X. Wu, Q. Li, H. Xin, A. Yu, and M. Zhong, "Effects of berberine on the blood concentration of cyclosporin $\mathrm{A}$ in renal transplanted recipients: clinical and pharmacokinetic study," European Journal of Clinical Pharmacology, vol. 61, no. 8, pp. 567-572, 2005.

[98] J. W. Budzinski, V. L. Trudeau, C. E. Drouin, M. Panahi, J. T. Arnason, and B. C. Foster, "Modulation of human cytochrome P450 3A4 (CYP3A4) and P-glycoprotein (P-gp) in Caco-2 cell monolayers by selected commercial-source milk thistle and goldenseal products," Canadian Journal of Physiology and Pharmacology, vol. 85, no. 9, pp. 966-978, 2007.

[99] I. M. Al-Masri, M. K. Mohammad, and M. O. Tahaa, "Inhibition of dipeptidyl peptidase IV (DPP IV) is one of the mechanisms explaining the hypoglycemic effect of berberine," Journal of Enzyme Inhibition and Medicinal Chemistry, vol. 24, no. 5, pp. 1061-1066, 2009.

[100] L. Xu, Y. Liu, and X. He, "Inhibitory effects of berberine on the activation and cell cycle progression of human peripheral lymphocytes," Cellular \& Molecular Immunology, vol. 2, no. 4, pp. 295-300, 2005.

[101] H. Li, B. Dong, S. W. Park, H. S. Lee, W. Chen, and J. Liu, "Hepatocyte nuclear factor $1 \alpha$ plays a critical role in PCSK9 gene transcription and regulation by the natural hypocholesterolemic compound berberine," Journal of Biological Chemistry, vol. 284, no. 42, pp. 28885-28895, 2009.

[102] S. Lin, S. C. Tsai, C. C. Lee, B. W. Wang, J. Y. Liou, and K. G. Shyu, "Berberine inhibits HIF-1 $\alpha$ expression via enhanced proteolysis," Molecular Pharmacology, vol. 66, no. 3, pp. 612619, 2004.

[103] C. L. Kuo, C. W. Chi, and T. Y. Liu, "Modulation of apoptosis by berberine through inhibition of cyclooxygenase-2 and Mcl-1 expression in oral cancer cells," In Vivo, vol. 19, no. 1, pp. 247-252, 2005.

[104] C. H. Lee, J. C. Chen, C. Y. Hsiang, S. L. Wu, H. C. Wu, and T. Y. Ho, "Berberine suppresses inflammatory agents-induced 
interleukin- $1 \beta$ and tumor necrosis factor- $\alpha$ productions via the inhibition of $\mathrm{I} \kappa \mathrm{B}$ degradation in human lung cells," Pharmacological Research, vol. 56, no. 3, pp. 193-201, 2007.

[105] S. Kim, Y. Kim, J. E. Kim, K. H. Cho, and J. H. Chung, "Berberine inhibits TPA-induced MMP-9 and IL-6 expression in normal human keratinocytes," Phytomedicine, vol. 15, no. 5, pp. 340-347, 2008.

[106] P. Abidi, Y. Zhou, J. D. Jiang, and J. Liu, "Extracellular signal-regulated kinase-dependent stabilization of hepatic low-density lipoprotein receptor mRNA by herbal medicine berberine," Arteriosclerosis, Thrombosis, and Vascular Biology, vol. 25, no. 10, pp. 2170-2176, 2005.

[107] J. Cameron, T. Ranheim, M. A. Kulseth, T. P. Leren, and K. E. Berge, "Berberine decreases PCSK9 expression in HepG2 cells," Atherosclerosis, vol. 201, no. 2, pp. 266-273, 2008.

[108] Y. Li, G. Ren, Y. X. Wang et al., "Bioactivities of berberine metabolites after transformation through CYP450 isoenzymes," Journal of Translational Medicine, vol. 9, article 62, 2011.

[109] S. Kim and J. H. Chung, "Berberine prevents UV-induced MMP-1 and reduction of type I procollagen expression in human dermal fibroblasts," Phytomedicine, vol. 15, no. 9, pp. 749-753, 2008.

[110] Y. Guo, Q. Z. Wang, F. M. Li, X. Jiang, Y. F. Zuo, and L. Wang, "Biochemical pathways in the antiatherosclerotic effect of berberine," Chinese Medical Journal, vol. 121, no. 13, pp. 1197-1203, 2008.

[111] Y. D. Min, M. C. Yang, K. H. Lee, K. R. Kim, S. U. Choi, and K. R. Lee, "Protoberberine alkaloids and their reversal activity of P-gp expressed multidrug resistance (MDR) from the rhizome of Coptis japonica makino," Archives of Pharmacal Research, vol. 29, no. 9, pp. 757-761, 2006.

[112] S. Lee, H. J. Lim, J. H. Park, K. S. Lee, Y. Jang, and H. Y. Park, "Berberine-induced LDLR up-regulation involves JNK pathway," Biochemical and Biophysical Research Communications, vol. 362, pp. 853-857, 2007.

[113] C. Y. Hsiang, S. L. Wu, S. E. Cheng, and T. Y. Ho, "Acetaldehyde-induced interleukin- $1 \beta$ and tumor necrosis factor- $\alpha$ production is inhibited by berberine through nuclear factor- $\kappa$ B signaling pathway in HepG2 cells," Journal of Biomedical Science, vol. 12, no. 5, pp. 791-801, 2005.

[114] J. P. Hu, K. Nishishita, E. Sakai et al., "Berberine inhibits RANKL-induced osteoclast formation and survival through suppressing the NF- $\kappa \mathrm{B}$ and Akt pathways," European Journal of Pharmacology, vol. 580, no. 1-2, pp. 70-79, 2008.

[115] D. C. Chao, L. J. Lin, S. T. Kao et al., "Inhibitory effects of Zuo-Jin-Wan and its alkaloidal ingredients on activator protein 1 , nuclear factor- $\kappa \mathrm{B}$, and cellular transformation in HepG2 cells," Fitoterapia, vol. 82, no. 4, pp. 696-703, 2011.

[116] H. L. Wu, C. Y. Hsu, W. H. Liu, and B. Y. Yung, "Berberineinduced apoptosis of human leukemia HL-60 cells is associated with down-regulation of nucleophosmin/B23 and telomerase activity," International Journal of Cancer, vol. 81, pp. 923-929, 1999.

[117] Y. Li, P. Wang, Y. Zhuang et al., "Activation of AMPK by berberine promotes adiponectin multimerization in 3T3-L1 adipocytes," FEBS Letters, vol. 585, no. 12, pp. 1735-1740, 2011.

[118] C. L. Kuo, C. W. Chi, and T. Y. Liu, "The anti-inflammatory potential of berberine in vitro and in vivo," Cancer Letters, vol. 203, no. 2, pp. 127-137, 2004.

[119] Y. S. Hsieh, W. H. Kuo, T. W. Lin et al., "Protective effects of berberine against low-density lipoprotein (LDL) oxidation and oxidized LDL-induced cytotoxicity on endothelial cells,"
Journal of Agricultural and Food Chemistry, vol. 55, no. 25, pp. 10437-10445, 2007.

[120] W. L. Hyun, H. S. Jung, H. N. Kim et al., "Berberine promotes osteoblast differentiation by Runx2 activation with p38 MAPK," Journal of Bone and Mineral Research, vol. 23, no. 8, pp. 1227-1237, 2008.

[121] Y. Qin, J. Y. Pang, W. H. Chen, Z. Z. Zhao, L. Liu, and Z. H. Jiang, "Inhibition of DNA topoisomerase I by natural and synthetic mono- and dimeric protoberberine alkaloids," Chemistry and Biodiversity, vol. 4, no. 3, pp. 481-487, 2007.

[122] K. Fukuda, Y. Hibiya, M. Mutoh, M. Koshiji, S. Akao, and H. Fujiwara, "Inhibition of activator protein 1 activity by berberine in human hepatoma cells," Planta Medica, vol. 65, no. 4, pp. 381-383, 1999.

[123] S. Kim, H. C. Jae, B. K. Jong et al., "Berberine suppresses TNF- $\alpha$-induced MMP-9 and cell invasion through inhibition of AP-1 activity in MDA-MB-231 human breast cancer cells," Molecules, vol. 13, no. 12, pp. 2975-2985, 2008.

[124] S. Mahata, A. C. Bharti, S. Shukla, A. Tyagi, S. A. Husain, and B. C. Das, "Berberine modulates AP-1 activity to suppress HPV transcription and downstream signaling to induce growth arrest and apoptosis in cervical cancer cells," Molecular Cancer, vol. 10, article 39, 2011.

[125] F. L. Chen, Z. H. Yang, Y. Liu et al., "Berberine inhibits the expression of TNFalpha, MCP-1, and IL-6 in AcLDLstimulated macrophages through PPARgamma pathway," Endocrine, vol. 33, no. 3, pp. 331-337, 2008. 

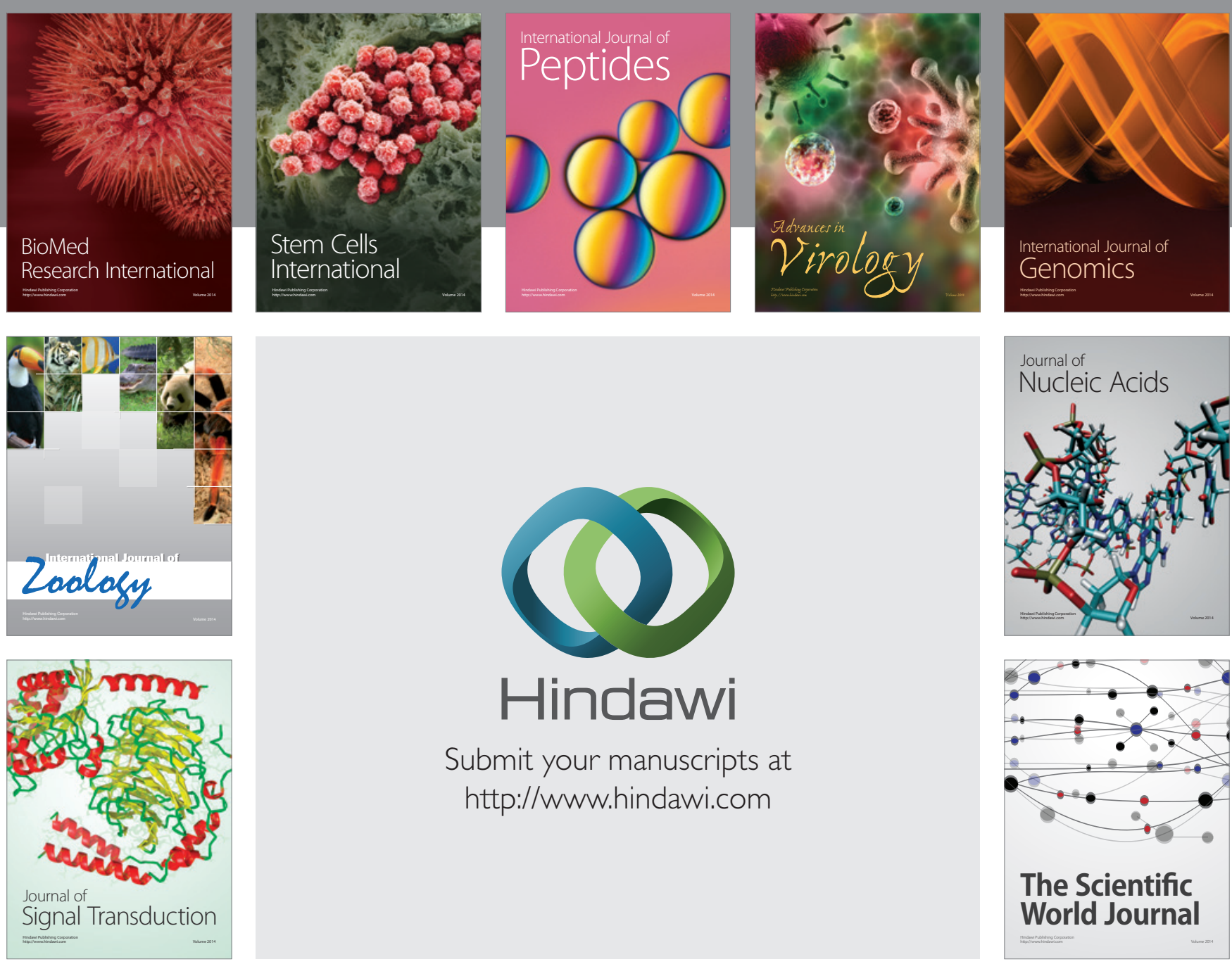

Submit your manuscripts at

http://www.hindawi.com
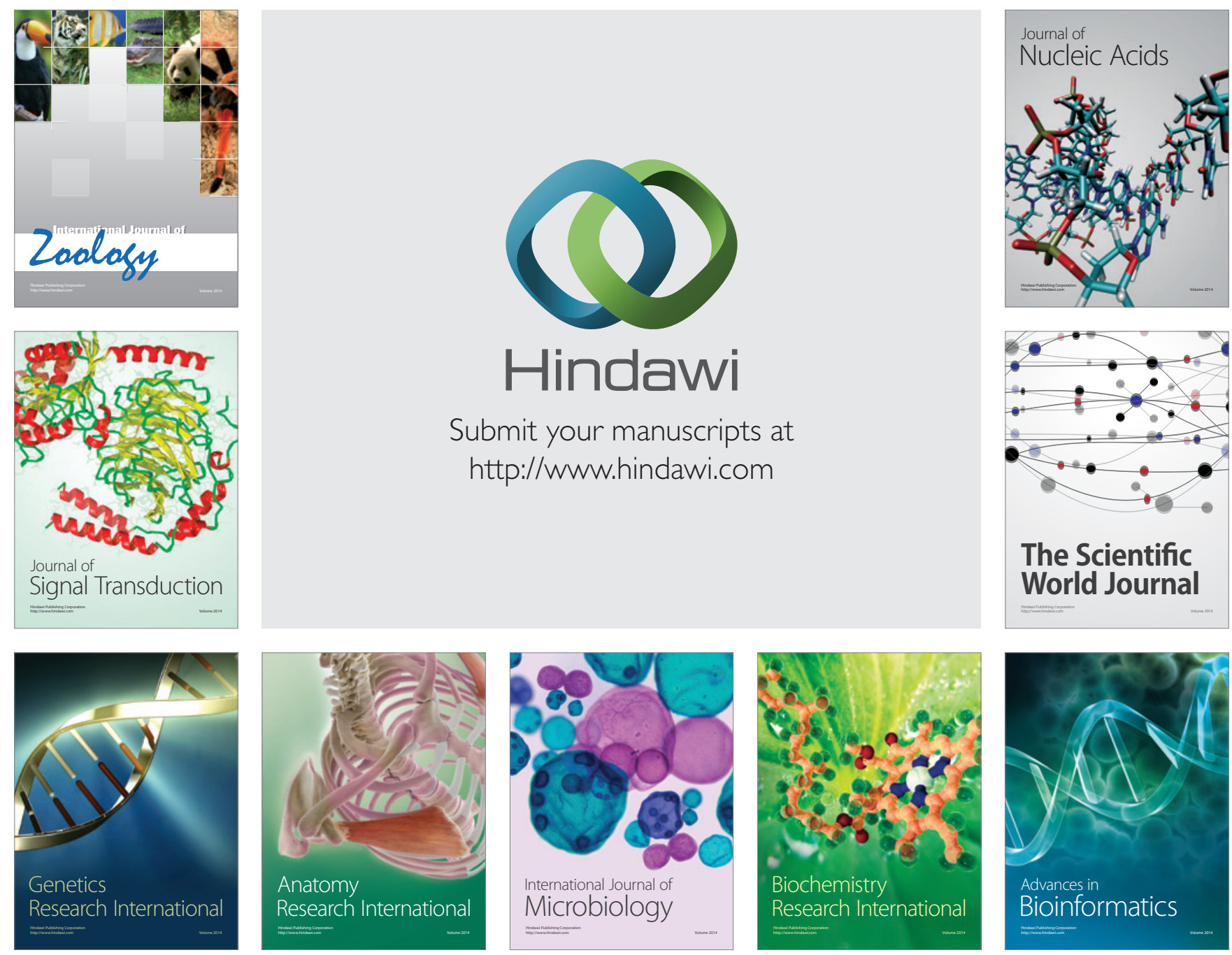

The Scientific World Journal
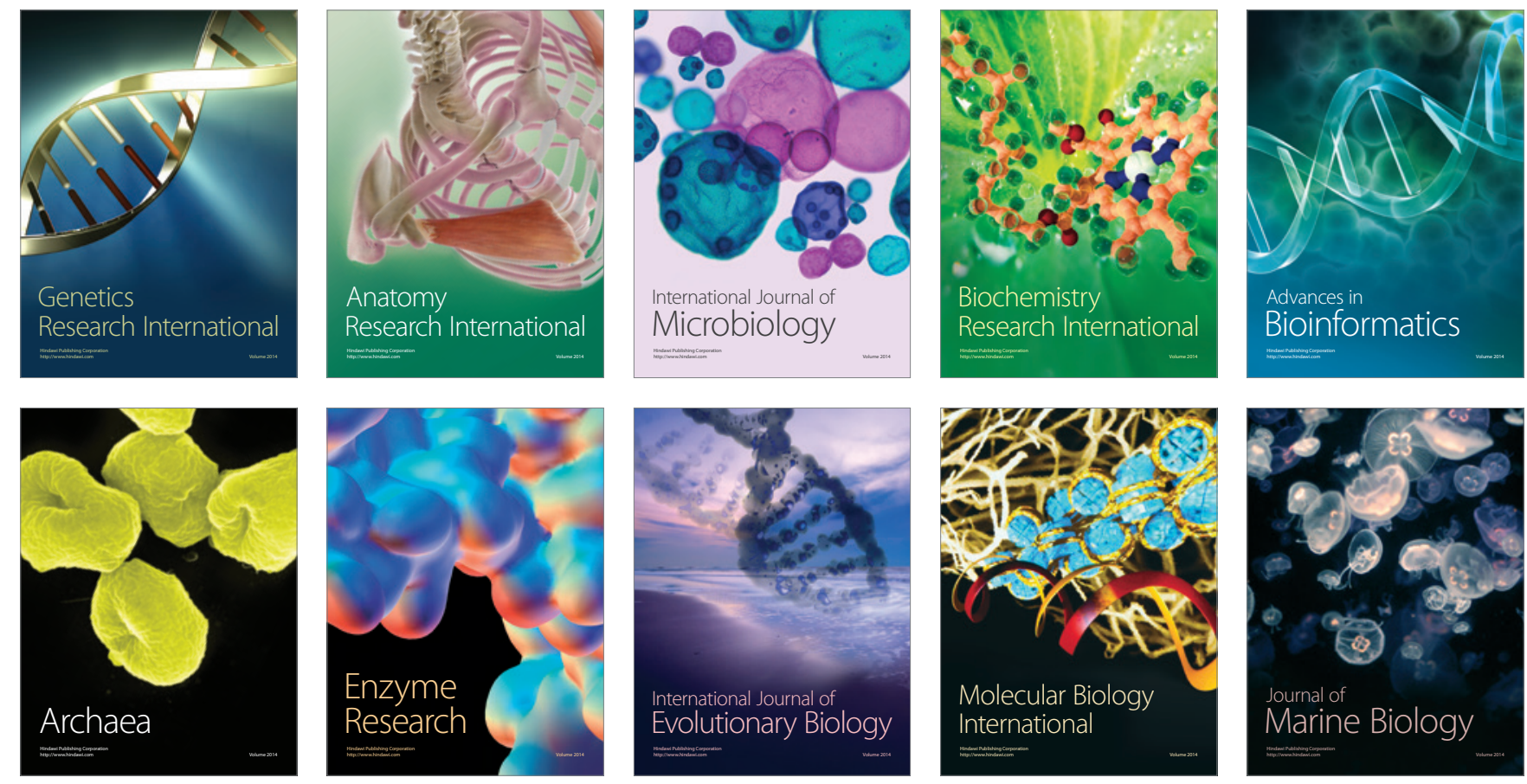